\title{
International PCAOB Inspections and Earnings Management Transmission within
}

\section{Multinational Business Groups *}

\author{
David Oesch ${ }^{\mathrm{a}}$, Felix Urban ${ }^{\mathrm{b}}$
}

May 28, 2019

\begin{abstract}
:
Does the impact of international Public Company Accounting Oversight Board (PCAOB) inspections extend beyond country borders of inspected auditors? We investigate this question by examining multinational business groups. Following initial PCAOB inspections of accounting firms auditing foreign U.S.-listed global ultimate owners, our findings indicate that their international subsidiaries decrease earnings management. Research design choices such as the comparison of treated observations with same country-industry-year control observations and a fixed effects structure that controls for country, industry, year, and group characteristics mitigate concerns of omitted variables. Our paper provides evidence for benefits of international PCAOB inspections over and above the previously documented effects for firms located in the countries of the inspected auditors.
\end{abstract}

JEL Classification: F23; M41; M42; M48

Keywords: PCAOB; PCAOB International Inspection Program; Positive Externality; Cross Listing; Multinational Companies; MNC; Transmission of Shocks

\footnotetext{
* We thank Charlie Cai, Chris Florackis, Lucas Knust, Alexandros Kostakis, Philip Ormrod, and seminar participants at the University of Liverpool for useful comments and discussions.

${ }^{a}$ Corresponding Author. University of Zurich, Department of Business Administration, Phoenixweg 5, 8032 Zurich, Switzerland. E-mail address: david.oesch@business.uzh.ch.

${ }^{\mathrm{b}}$ University of Zurich, Department of Business Administration, Phoenixweg 5, 8032 Zurich, Switzerland. E-mail address: felix.urban@business.uzh.ch.
} 


\section{Introduction}

The Public Company Accounting Oversight Board (PCAOB) regularly inspects accounting firms that perform audits, issue audit reports, or provide related services for U.S.listed companies. This also applies to non-U.S. auditors performing such tasks for U.S.-listed firms not located in the U.S. An extensive stream of literature documents improvements in audit quality for audit clients of U.S. and non-U.S. auditors after their initial PCAOB inspection (see, e.g., Carcello, Holligsorth, and Mastrolia, 2011; Gramling, Krishnan, and Zhang, 2011; Abbott, Gunny, and Zhang, 2013; Gunny and Zhang, 2013; Boone, Khurana, and Raman, 2015; Defond and Lennox, 2011; Defond and Lennox, 2017; Fung, Raman, and Zhu, 2017; Gipper, Leuz, and Maffett, 2019; Krishnan, Krishnan, and Song, 2017). Our paper focuses on initial PCAOB inspections of non-U.S. auditors and investigates their international transmission effects.

We analyze the international transmission within multinational business groups (i.e. business groups consisting of a global ultimate owner (GUO) and subsidiaries that are located in a different country than their GUO). We document a transmission effect of initial PCAOB inspections concerning non-U.S. auditors of foreign U.S.-listed GUOs within the business group that results in a reduction of earnings management of the GUOs' international subsidiaries. In doing so, our study furthers the understanding of the effects of international PCAOB inspections on audit clients' international subsidiaries. Our paper also provides evidence for international benefits of foreign PCAOB inspections over and above the benefits for firms located in the country of the inspected auditor as documented in prior literature.

Recent papers document a potential cross-country transmission effect between the members of multinational business groups (see, e.g., Cravino and Levchenko, 2017; Bena, Dinc, and Erel, 2019). In addition, literature shows extensive GUO power on subsidiaries' financial structure, operating activities, and financial reporting activities (see, e.g., Dyreng, Hanlon, and Maydew, 2012; Robinson and Stocken, 2013; Shroff, Verdi, and Yu, 2014; 
Beuselinck, Cascino, Deloof, and Vanstraelen, 2018). Therefore, we hypothesize that initial PCAOB inspections of GUO auditors have an effect on the earnings management of international subsidiaries.

However, the direction of such a transmission effect on subsidiary-level earnings management is not obvious. On the one hand, GUOs could shift earnings management from the consolidated group level to international subsidiaries after an increase in audit quality at the consolidated reports level arising from initial PCAOB inspections of their auditor. This hypothesis is supported by Beuselinck et al. (2018), who show that GUOs located in relatively strict jurisdictions shift earnings management to international subsidiaries located in jurisdictions with weaker regulations.

On the other hand, earnings management of international subsidiaries could decrease following an initial PCAOB inspection of the GUO auditor. GUO managers could influence subsidiary managers to align earnings management practices with the improved audit quality at the consolidated accounts level. In addition, GUO managers could aim to lower earnings management of international subsidiaries as managing earnings at the level of international subsidiaries increases the circle of people that are aware of these accounting practices and automatically raises the risk of detection (Dyreng et al., 2012).

We download ownership, financial, and auditor data from Bureau van Dijk's Orbis database and define a GUO as a firm that directly or indirectly holds at least $50.01 \%$ in a subsidiary and is itself not owned by a single corporate shareholder by more than $25 \%$ or by a single non-corporate shareholder by more than $50 \%$. We compare a treatment and a control group to examine whether initial PCAOB inspections of the GUO auditor have an effect on international subsidiaries. We classify international subsidiaries as part of our treatment sample if the auditor of their foreign U.S.-listed GUO is initially PCAOB-inspected. We construct a two-year window for treated subsidiaries around the inspection year consisting of the year prior to and the year after the inspection. International subsidiaries in the control group have a foreign 
U.S.-listed GUO but do not experience an initial PCAOB inspection of their GUO's auditor before or during our sample period. We retain subsidiary observations from the same countryindustry-year group as treated subsidiaries for the control group.

We focus on non-U.S. auditors experiencing an initial PCAOB inspection between 2009 and 2016. Our version of Orbis provides subsidiary financial data for ten years (in our case 2008 through 2017). Since we analyze the years before and after an inspection as described above, we cover inspections between 2009 and 2016. ${ }^{1}$ The final sample contains 744 subsidiary-year observations for the treated group and 2,815 subsidiary-year observations for the control group.

We measure subsidiary earnings management using absolute discretionary accruals. Following Beuselinck et al. (2018), we construct our measure as the absolute value of the residuals from a performance-adjusted modified Jones model (Dechow, Sloan, and Sweeney, 1995; Kothari, Leone, and Wasley, 2005). We focus on absolute abnormal accruals (a proxy for accounting discretion) rather than on signed abnormal accruals (a proxy for audit quality) for two reasons. First, we are interested in the transmission effect on subsidiary accounting discretion irrespective of whether it is applied to increase or decrease earnings. Second, we do not analyze firms that are directly audited by inspected auditors and therefore audit quality may not be an appropriate measure to examine a transmission effect on subsidiaries.

Our regression estimates document a decrease in earnings management of international subsidiaries with U.S.-listed GUOs in the year following an initial PCAOB inspection of the GUO's non-U.S. auditor. Our baseline regression model controls for a number of subsidiary characteristics that could determine earnings management. The baseline regression also includes subsidiary-country, subsidiary-industry, year, and GUO-country fixed effects to

\footnotetext{
${ }^{1}$ Therefore, we cannot investigate initial PCAOB inspections of auditors before the sample period but focus on non-U.S. auditors that were initially inspected during our sample period (e.g. we do not include the initial PCAOB inspection of BDO UK in 2006 in our sample, but we investigate the initial PCAOB inspection of Deloitte UK in 2010).
} 
control for potential determinants of subsidiary-level earnings management that are specific to a subsidiary country, a subsidiary industry, a year, or a GUO country. We continue to find a significantly negative effect on subsidiary earnings management when we replace GUOcountry fixed effects with group fixed effects to control for time-invariant GUO attributes (that include, but go beyond, a GUO's country). Our documented effect is also economically significant. The main result reveals an average decrease of $17.38 \%$ of the pre-inspection standard deviation in absolute discretionary accruals following an initial PCAOB inspection of the GUO auditor.

Our effect is corroborated by a number of robustness tests. We continue to find a significantly negative effect of a foreign GUO's auditor's initial PCAOB inspection on subsidiary earnings management when we additionally control for various GUO earnings management incentives. We also show that our results are not unduly influenced by individual countries that make up significant parts of our sample. In addition, we verify our earnings management proxy by including control variables that were used in the regression to determine our earnings management measure and by varying the construction of our proxy. Additional analyses show that our documented effect on subsidiary earnings management is larger for international subsidiaries located in countries that permit PCAOB inspections.

A major advantage of our setting is the staggered nature of initial foreign PCAOB inspections over years, countries, and audit firms. Due to the international ownership structure of our sample, the treatment of subsidiaries in our sample is staggered over years, subsidiary countries, GUO countries, and GUO auditors. This substantially raises the bar for omitted variables or reverse causality as alternative explanations for our results.

The empirical implementation of our research question aims to further reduce endogeneity concerns. First, we employ a control group and an extensive fixed effects structure to isolate the effect of a PCAOB inspection of the GUO auditor on subsidiaries' earnings management. The strict requirements for control observations ensure that differences in the 
subsidiary country, in the subsidiary industry, or in years do not drive our results. The fixed effects structure employed in our estimations also helps decrease the likelihood of omitted variables confounding our inferences. Second, GUO characteristics could correlate with both subsidiary earnings management and PCAOB initial inspections. However, as the focus of PCAOB inspections are primarily auditors, but not audit clients or their subsidiaries, such a correlation seems unlikely. Nevertheless, we control for correlated time-invariant GUO characteristics by using group fixed effects in our main model, and we control for time-variant GUO characteristics related to GUO earnings management incentives in additional tests. Overall, the staggered nature of inspections, our strict requirements for the control group, the use of a tight fixed effects structure, and the inclusion of control variables mitigate concerns regarding alternative explanations of our findings.

Our study contributes to the literature in three major ways. First, to our knowledge, our paper is the first to investigate the effect of PCAOB inspections on multinational business groups. Krishnan et al. (2017) document an improvement in the audit quality of U.S.-listed foreign audit clients after PCAOB inspections. It is unclear if this improvement spills over to international subsidiaries' earnings management. On the one hand, Beuselinck et al. (2018) document a shift of earnings management from GUOs to international subsidiaries when the strictness of regulations increases in the GUO country. On the other hand, related studies suggests that, after PCAOB inspections, the audit quality also increases for firms that are not in the scope of the regulations assessed by the PCAOB (see, e.g., Fung et al., 2017). We contribute to these studies by documenting a decrease in earnings management of international subsidiaries of audit clients after PCAOB inspections.

Second, we contribute to the research on externalities of international PCAOB inspections by introducing an additional international dimension. Fung et al. (2017) provide evidence for externalities on non-U.S.-listed clients of inspected auditors and hence document positive effects on firms for which the U.S. regulations assessed by the PCAOB do not apply. 
While they study firms located in the country of the inspected auditor, our paper, to our knowledge, is the first study to examine the effect on firms not located in the country of the inspected auditor. Additionally, literature on both U.S. and non-U.S. inspections focuses on the benefits for direct clients of inspected auditors (see, e.g., Carcello et al., 2011; Gramling et al., 2011; Abbott et al., 2013; Gunny and Zhang, 2013; Boone et al., 2015; Defond and Lennox, 2017; Fung et al., 2017; Gipper et al., 2019; Krishnan et al., 2017). In investigating the effect of a GUO-auditor inspection on international subsidiaries, we extend this research by providing evidence of benefits for firms that are not directly audited by the PCAOB-inspected accounting firms in our sample.

Third, we contribute to the nascent stream of literature studying cross-border transmission effects within multinational business groups. We extend this research by documenting a transmission effect of an auditor inspection at the GUO level on accounting practices of international subsidiaries. Our findings add to the evidence provided by Beuselinck et al. (2018) who examine the characteristics that influence the degree of earnings management pressure put on international subsidiaries by GUOs. We also extend research by Cravino and Levchenko (2017) and Bena et al. (2019) who analyze the transmission effects within multinational business groups. While Cravino and Levchenko (2017) document a transmission of business cycles between GUOs and international subsidiaries, Bena et al. (2019) show a transmission effect of crises between international subsidiaries. We find that international subsidiaries decrease their earnings management practices following an auditor inspection at the consolidated reports level. This provides evidence of potential earnings management alignment across borders within multinational business groups.

The remainder of this paper is organized as follows. Section 2 presents background information and develops the hypothesis. Section 3 describes the data sources, research design, and sample construction. We discuss the main results and robustness tests in Section 4. Section 5 contains concluding remarks. 


\section{PCAOB International Inspections \& Hypothesis Development}

\subsection{PCAOB International Inspections}

The PCAOB was established through the Sarbanes-Oxley Act of 2002. With the aim of improving audit quality of U.S.-listed firms, the PCAOB has the authority to perform inspections of PCAOB-registered auditors. Accounting firms need to register with the PCAOB if they perform audits, issue audit reports, or provide services with regards to such reports for U.S.-listed companies. This applies to both U.S. and non-U.S. audit firms. During inspections, the PCAOB assesses auditors' compliance with the Sarbanes-Oxley Act, PCAOB policies, the regulations of the Security and Exchange Commission (SEC), and professional standards.

The PCAOB began with inspections of U.S. auditors in 2004 and with inspections of non-U.S. auditors (i.e. international inspections) in 2005. In addition to the first (i.e. initial) inspection, auditors that regularly issue audit reports for more than 100 U.S.-issuers are inspected annually, auditors that regularly issue less than 100 audit reports for U.S.-issuers are generally inspected at least once every three years (Krishnan et al., 2017; Fung et al., 2017). Foreign initial inspections were staggered over time, countries, and audit firms. The PCAOB provides inspection reports with information on applied inspection methodologies and audit quality issues. Additionally, it provides detailed information on quality control issues if auditors fail to address such issues satisfactorily within 12 month after the report date. ${ }^{2}$

We focus on initial international PCAOB inspections in our analysis, specifically on subsidiaries if the non-U.S. auditor of their foreign U.S.-listed GUO is initially PCAOBinspected.

\footnotetext{
${ }^{2}$ Information on unsatisfactorily addressed quality control issues are provided on the official PCAOB website https://pcaobus.org.
} 


\subsection{Prior Literature and Hypothesis Development}

While an extensive stream of literature provides evidence for benefits arising from public oversight bodies that overview the audit profession (see, e.g., Lamoreaux, 2016; Carson et al., 2017), the most prominent and discussed national public accounting oversight body is the PCAOB. ${ }^{3}$ Literature documents an improvement in audit quality after PCAOB inspections of U.S. auditors (see, e.g., Carcello et al., 2011; Gramling et al., 2011; Abbott et al., 2013; Gunny and Zhang, 2013; Boone et al., 2015; Defond and Lennox, 2017). ${ }^{4}$ Further studies find that international PCAOB inspections are associated with higher audit quality for both U.S.listed and non-U.S.-listed audit clients of inspected non-U.S. auditors (Krishnan et al., 2017; Fung et al., 2017). In doing so, this literature provides evidence for positive externalities of international PCAOB inspections on non-U.S.-listed public firms, even though these are not the intended subjects of PCAOB inspections (Fung et al., 2017). ${ }^{5}$

We hypothesize that initial international PCAOB inspections have an effect on international subsidiaries of foreign U.S.-listed clients that are audited by an inspected auditor. Consider company X that is located in Australia and listed in the U.S. Company X is the GUO of subsidiary Y. Subsidiary Y is located in Italy (i.e. it is an international subsidiary). Ernst \& Young Australia audits the financial reports of company X. In our study, we analyze the transmission effect of the initial PCAOB inspection of Ernst \& Young Australia on subsidiary Y, specifically its earnings management. A change in subsidiary earnings management would arise from a transmission of an event at the GUO level to the subsidiary level. While it is not a

\footnotetext{
${ }^{3}$ Carson et al. (2017) find an improvement in audit quality after initial auditor inspections by national public oversight bodies. Lamoreaux (2016) provides evidence for positive effects on audit quality arising from an existing threat of PCAOB inspections following the admission of PCAOB inspections in countries.

${ }^{4}$ These papers document subsequent improvements in audit quality. Gipper, Leuz, and Maffett (2019) analyze the effect on how investors evaluate audit quality following PCAOB inspections. They find that reporting credibility increases after such inspections.

${ }^{5}$ Studies covering effects of PCAOB inspections on non-accounting outcomes are rare. Carcello, Carver, and Neal (2011) document a negative reaction of investors to the information that PCAOB international inspections are not allowed in a country. Shroff (2017) shows an increase in external capital and investment in periods after PCAOB inspections.
} 
priori clear if such a transmission effect exists, a nascent literature in accounting, economics, and finance has started to provide evidence of possible transmissions within multinational groups.

Recent literature analyzes transmissions of business cycles and financial decisions within multinational business groups (see, e.g., Shroff et al., 2014; Cravino and Levchenko, 2017; Di Giovanni, Levchenko, and Mejean, 2018; Tweedle, 2018; Beaver et al., 2019). ${ }^{6}$ In addition to the vertical transmission of shocks between GUOs and subsidiaries, shocks can also be transmitted horizontally between subsidiaries of multinational groups in different countries. Bena et al. (2019) document a decrease of investment in international subsidiaries if other international subsidiaries of the same group are located in countries experiencing an economic crisis. ${ }^{7}$ In addition, studies provide evidence for extensive GUO power on international subsidiaries' financial structure, operating activities, and financial reporting activities (see, e.g., Aylmer, 1970; Dyreng, Hanlon, and Maydew, 2012; Robinson and Stocken, 2013; Beuselinck et al., 2018). Chen and Conaway (2019) document positive market reactions for GUOs that are both U.S.-domiciled and U.S.-listed upon the announcement of international PCAOB inspections in the countries of their foreign subsidiaries.

The literature analyzed above provides evidence for improvements in audit quality of foreign U.S.-listed firms after initial PCAOB inspections of their auditor (Krishnan et al., 2017). In addition, studies analyze possible transmission effects within multinational business groups (Shroff et al., 2014; Cravino and Levchenko, 2017; Bena et al., 2019; Beuselinck et al., 2018). We analyze the transmission effect of an initial PCAOB inspection of the foreign U.S.-listed GUO's auditor on international subsidiaries' earnings management. The direction of the effect on earnings management at the international subsidiary level is not a priori clear. On the one

\footnotetext{
${ }^{6} \mathrm{~A}$ range of papers also analyzes tax-motivated income shifting within multinational business groups (see, e.g., De Simone, 2016; De Simone, Klassen, and Seidman, 2017; Klassen, Lisowsky, and Seidman, 2017; Hopland et al., 2018).

${ }^{7}$ The majority of the literature on multinational business groups uses ownership data from Orbis to construct links between GUOs and subsidiaries.
} 
hand, GUOs could shift earnings management from the consolidated group level to the level of international subsidiaries after an increase in audit quality at the consolidated level arising from initial PCAOB inspections of their auditor. Literature provides examples for such strategies. Beuselinck et al. (2018) show that GUOs located in jurisdictions with stricter regulations shift earnings management to the international subsidiary level of subsidiaries located in jurisdictions with weaker regulations. Hence, GUO managers could decide to shift earnings management to the level of international subsidiaries after the audit quality increase at the consolidated reports level arising from initial PCAOB inspections. ${ }^{8}$

On the other hand, earnings management of international subsidiaries with foreign U.S.listed GUOs could decrease following an initial PCAOB inspection of the GUO's non-U.S. auditor. As discussed above, an extensive stream of literature provides evidence for improvements in audit quality following PCAOB inspections. Therefore, GUO managers could influence subsidiary managers to align earnings management practices with the improved audit quality at the consolidated accounts level. This could be a cautionary step to avoid reputational penalties if the GUO auditor detects aggressive earnings management at the international subsidiary level, as GUO managers cannot gauge the extent of increased scrutiny by auditors prior to the first audit after the initial PCAOB inspection. As the PCAOB also detects audit deficiencies relating to auditors' reliance on other auditors, it is plausible that GUO auditors improve their scrutiny of other auditors' work (e.g. subsidiary auditors) after PCAOB inspections (Carson et al., 2018).

In addition, managing earnings at the level of international subsidiaries increases the circle of people that are aware of such accounting practices (Dyreng et al., 2012). This automatically increases the risk of discovery, especially in periods with improved audit

\footnotetext{
${ }^{8}$ Additionally, Beuselinck et al. (2018) show that the influence of GUOs on subsidiary earnings management varies with subsidiary integration and the degree of earnings management opportunities.
} 
investigations as GUO managers cannot gauge the extent of auditors' additional analyses and more detailed investigations ex ante.

Awareness of PCAOB inspections and resulting closer audit scrutiny also play a major role for the effects on subsidiaries' accounting practices (see, e.g., Fung et al., 2017). Hence, initial PCAOB inspections of GUO auditors could increase awareness of the effects arising from more detailed audit inspections for managers of international subsidiaries. As a result, managers of foreign international subsidiaries could decide to lower earnings management to reduce the likelihood of negative consequences arising from potential closer inspections.

Based on these arguments, we hypothesize that the degree of international subsidiary earnings management changes following initial international PCAOB inspections of foreign U.S.-listed GUO auditors. We formulate the following hypothesis in the null form as the directional effect on earnings management is a priori unclear:

H1: There is no effect of an initial PCAOB inspection concerning the auditor of a foreign U.S.-listed GUO on earnings management of its international subsidiaries.

\section{Data, Methodology, and Sample Construction}

\subsection{Data and Group Construction}

\subsubsection{Data}

We obtain ownership, financial, and auditor data from the web-interface of Orbis, a database provided by Bureau van Dijk. By collecting firm data from annual reports and national databases, Orbis provides information on private and listed companies. In addition to financial data, Orbis provides ownership information that enables the construction of ownership links between companies. As Orbis relies to a large extent on information provided by national registries, data availability depends on the reporting requirements of national jurisdictions. Even though this results in cross-country variations of private firm coverage, studies show that cross-country coverage of private firms is comparable to other databases such as Eurostat 
(Kalemli-Ozcan et al., 2015; Alfaro and Chen, 2018). Ownership data provided by Orbis is static and presented as of the day the latest information was provided to Orbis. ${ }^{9,} 10$

We obtain data on PCAOB-inspected auditors from the official website of the PCAOB. ${ }^{11}$ It is crucial to identify the first PCAOB inspection report of an audit firm as we follow Krishnan et al. (2017) and Fung et al. (2017) and focus on the effect of the initial PCAOB inspection of foreign auditors. To this end, we manually analyze PCAOB reports and link initial PCAOB inspection dates to all legal entity names under which the inspected auditor has issued reports. ${ }^{12}$ We examine initial international PCAOB inspections from 2009 through 2016. Foreign PCAOB inspections started in 2005. However, our version of Orbis provides subsidiary financial data for ten years (in our case 2008 through 2017). We obtain macroeconomic data from the International Monetary Fund (IMF) World Economic Outlook Database through the website of the IMF. We download GDP data based on purchasing-power-parity per capita and inflation data based on average consumer prices. ${ }^{13}$

\footnotetext{
${ }^{9}$ If e.g. subsidiary $\mathrm{Y}$ becomes a member of multinational group X in 2014 and ownership information downloaded in 2018 was last updated in 2017 for group X, we treat subsidiary Y as member of the group X for the entire sample period from 2008 to 2017. As a consequence, if group X's GUO auditor is audited in 2011, we would assign a GUO-auditor inspection to subsidiary Y in the year 2011, even though it was not a member of group X in 2011. Similarly, we treat subsidiary Z that left group W in 2014 as not being a member of group W for the entire sample period from 2008 to 2017. At the same time, we would not link the inspection of group W's GUO auditor in 2011 to subsidiary Z, even though it was a member of the group in 2011. As a consequence, the static nature of Orbis ownership data could lead to a measurement error. However, if anything, this would work against us in our empirical estimation.

${ }^{10}$ Cravino and Levchenko (2017) also use Orbis data to construct multinational group structures. They analyze whether changes in ownership that are not considered due to the static nature of Orbis' ownership data influence their results. To do so, they compare the ownership structure information from Orbis obtained at two different points in time. Specifically, they compare the ownership structure from the download of the data they use with the ownership structure from three years earlier (they obtain this data from an older Orbis vintage on a DVD-ROM) to obtain ownership changes. They first exclude subsidiaries for which they observe a change in ownership. Second, they keep subsidiaries without an observed change in ownership. Throughout these tests, they show that the ownership changes do not influence their results.

${ }^{11}$ Information on PCAOB-inspected auditors is obtained from https://pcaobus.org/Inspections/Reports/Pages/ default.aspx.

${ }^{12}$ For instance, the initial PCAOB inspection report for Deloitte Accountants B.V. in the Netherlands mentions that Deloitte Accountants B.V. has also issued audit reports under the name DT Accountants BV (https://pcaobus.org/Inspections/Reports/Documents/2015_Deloitte_Accountants_B_V.pdf). The inspection date of this report is assigned to both Deloitte Accountants B.V. and DT Accountants BV.

${ }^{13}$ We download GDP data from the IMF World Economic Outlook Database subject "Gross domestic product based on purchasing-power-parity (PPP) valuation of country GDP (current international dollar)" and inflation data from the subject "Inflation, average consumer prices (index)".
} 


\subsubsection{Group Construction and Data Preparation}

We analyze the transmission effect of a PCAOB inspection at the GUO-auditor level within a multinational business group, more specifically on international subsidiaries. Therefore, we define a GUO and its subsidiaries as members of the same business group. Our group construction follows two steps. In the first step, we download data on firms that are classified as GUOs from Orbis. In doing so, we define GUOs as firms that own at least 50.01\% directly or indirectly in a subsidiary. Additionally, a corporate shareholder must not own more than $25 \%$ in a GUO. ${ }^{14}$ In this GUO-level download, Orbis does not provide data on noncorporate GUOs such as individuals and families. Therefore, this approach excludes noncorporate GUOs. ${ }^{15,16}$ For the download, we prefer annual reports over local registry filings. We follow Shroff et al. (2014) and Beuselinck et al. (2018) and obtain data from consolidated accounts of GUOs. In the second step, we download data for subsidiaries of the previously defined GUOs through the subsidiary-GUO information in Orbis. ${ }^{17}$ Orbis provides a variable indicating the GUO of a subsidiary. We prefer local registry filings over annual reports and require that unconsolidated accounts are available for subsidiaries (this approach follows Cravino and Levchenko (2016)). We exclude GUOs and subsidiaries with no recent or limited financial information in both steps. We download GUO and subsidiary financial data as well as GUO-auditor data from 2008 to 2017, as data availability of our Orbis web-interface version is constrained to ten years. We download financial data in U.S. Dollar.

Subsidiaries within a group have the same GUO that holds at least $50.01 \%$ directly or indirectly in the subsidiaries. We define international subsidiaries as subsidiaries located in a

\footnotetext{
${ }^{14} \mathrm{We}$ classify corporate shareholders as companies of the following types: banks and financial companies, insurance companies, corporate companies, private equity firms, hedge funds, venture capital, mutual and pension funds/trusts, publicly listed companies.

${ }^{15}$ Orbis assigns non-corporate GUOs to subsidiaries. However, information on this GUO-type is only available in subsidiary-level downloads.

${ }^{16}$ Due to this approach and the filters described above, individuals and families can own between $25 \%$ and $50 \%$ of a GUO.

${ }^{17}$ We use BvD ID numbers to identify subsidiaries of the previously defined GUOs.
} 
different country than the GUO and drop subsidiaries that do not fulfill this definition. ${ }^{18} \mathrm{We}$ only keep subsidiaries where both GUOs and subsidiaries have more than U.S. $\$ 10,000$ turnover and total assets in at least one year of the selected period (this requirement follows Shroff et al. (2014)). We exclude subsidiaries and subsidiaries with GUOs from financial and utilities industries (primary two-digit NACE Rev. 2 codes 64-66, 35-39).

We download GUO information regarding current and previous auditors as well as auditor appointment and resignation dates. We exclude subsidiary-year observations without available data on GUO auditors. ${ }^{19}$ Following Kalemli-Ozcan et al. (2015), we drop subsidiaryyear observations where the country codes generated from BvD IDs do not correspond to country codes provided in Orbis and if total assets, turnover, and employees information are missing simultaneously. We also exclude the entire subsidiary from our sample if total assets, tangible fixed assets, or the number of employees is negative in any of the years.

\subsection{Measure of Earnings Management}

We measure the magnitude of subsidiary-level earnings management by the absolute value of discretionary accruals. We follow Beuselinck et al. (2018) and apply a performanceadjusted modified Jones model (Dechow et al., 1995; Kothari et al., 2005) to measure discretionary accruals using the residuals of the following regression:

$$
\begin{aligned}
\frac{T C A_{s, t}}{T A_{s, t-1}}=\beta_{0} & \frac{1}{T A_{s, t-1}}+\beta_{1} \frac{\left(\Delta R E V_{s, t}-\Delta R E C_{s, t}\right)}{T A_{s, t-1}}+\beta_{2} R O A_{s, t-1} \\
& +\beta_{3} \text { INFLATION }_{c, t-1}+\text { GDP_GROWTH } H_{c, t-1}+\varepsilon_{s, t}
\end{aligned}
$$

\footnotetext{
${ }^{18}$ This approach defines a multinational business group if at least one international subsidiary is a member of the group. We vary the number of international subsidiaries required to define a multinational group in untabulated robustness tests. The canon of our main result remains unchanged if we require multinational groups to have at least 10, 20, 30, or 40 international subsidiaries.

${ }^{19}$ We define GUO auditors for subsidiary-year observations by using information on previous and current GUO auditors from Orbis. For previous GUO auditors, we define GUO-auditor tenure by appointment and resignation dates. GUO-auditor tenure for current auditors is defined as period after the appointment date. We assign GUO auditors to subsidiary-year observations within the GUO-auditor tenure. We exclude subsidiary-year observations if this approach provides more than one GUO auditor for a subsidiary-year observation.
} 
where $s, t$, and $c$ index subsidiaries, years, and countries. For the estimation of regression (1), we follow existing literature and pool observations across industries and year groups while we require each group to have at least ten observations (see, e.g., Beuselinck et al., 2018; Chaney et al., 2011; Krishnan et al., 2017). Discretionary accruals are measured for each subsidiaryyear observation as the residual from the regression. $T C A_{s, t}$ describes the total current accruals of subsidiary $s$ in year $t$ and is calculated as

$$
T C A_{s, t}=\left(\Delta C A_{s, t}-\Delta C A S H_{s, t}\right)-\left(\Delta C L_{s, t}-\Delta S T D_{s, t}\right)-\text { DEPRECIATION }_{s, t}
$$

where $\Delta C A_{s, t}, \Delta C A S H_{s, t}, \Delta C L_{s, t}$, and $\Delta S T D_{s, t}$ describe the change in total current assets, cash and cash equivalents, current liabilities, and short-term debt of subsidiary $s$ from year $t-1$ to $t$. $T A_{s, t-1}$ denotes total assets and $R O A_{s, t-1}$ denotes return on assets of subsidiary $s$ in year $t-1$. $\triangle R E V_{s, t}$ and $\triangle R E C_{s, t}$ are the changes in revenues and receivables of subsidiary $s$ from $t-1$ to $t$, respectively. INFLATION $N_{c, t-1}$ controls for inflation and GDP_GROWTH $H_{c, t-1}$ for change in real purchasing power based GDP, both measuring the respective value in country $c$ for year $t$ 1. We follow Beuselinck et al. (2018) for the construction of the model using subsidiary financial data from Orbis and economic data from the IMF World Economic Outlook Database. $^{20}$

We analyze the degree of accounting discretion applied through earnings management by using the absolute value of discretionary accruals as dependent variable for two reasons. First, the signed value could be interpreted as a proxy for audit quality. Whereas audit quality is of major interest at the U.S.-listed GUO level due to the inspection of its auditor, we aim to measure the transmission effect on international subsidiaries' degree of accounting discretion irrespective of whether it is applied to increase or decrease earnings. Hence, we use absolute discretionary accruals instead of signed accruals. Whereas lower signed discretionary accruals

\footnotetext{
${ }^{20}$ Our estimation of accruals follows the balance sheet approach. This estimation could miscalculate accruals if non-operating events (e.g. mergers, divestitures) impact current assets and liabilities while they do not influence earnings (Hribar and Collins, 2002). However, it is not possible to calculate accruals with the cash flow approach due to the data availability of subsidiaries' cash flow information.
} 
indicate higher audit quality, we measure earnings management through the absolute value, as we aim to measure the degree of accounting discretion, irrespective of the direction of earnings management. Second, we do not analyze firms that are directly audited by inspected accounting firms but subsidiaries of these firms. Hence, audit quality may not be the appropriate measure to analyze the transmission effect of PCAOB inspections.

\subsection{Methodology}

We analyze the transmission effect of international PCAOB inspections concerning auditors of foreign U.S.-listed GUOs on their international subsidiaries' earnings management. We implement this analysis by defining a treatment and control group. International subsidiaries are treated if the auditor of their foreign U.S.-listed GUO is initially PCAOBinspected.

We analyze the effect on earnings management of treated subsidiaries from the preinspection to the post-inspection year. Therefore, we construct a two-year window consisting of the year before and the year following the initial PCAOB inspection of the GUO auditor for our treatment group. We define the year of the final PCAOB inspection report and classify international subsidiaries as treated if their foreign U.S.-listed GUO is audited by an initially inspected auditor. ${ }^{21}$ Ideally, we could compare an international subsidiary in the year following the initial PCAOB inspections of the GUO auditor with the same subsidiary that did not experience the treatment. As this is not possible, we use a control group. For the construction of the control group, we start with all international subsidiaries of foreign U.S.-listed GUOs. We exclude subsidiaries whose GUO auditor experiences an initial PCAOB inspection before or during our sample period. We retain subsidiary-year observations from the same country-

\footnotetext{
${ }^{21}$ We follow prior literature (see, e.g., Fung et al., 2017; Krishnan et al., 2017) for the analysis around the year of the final PCAOB inspection report.
} 
industry-year combinations as treated subsidiaries (Krishnan et al., 2017). ${ }^{22}$ We exclude treated subsidiaries if no control observations are available for the country-industry-year combination. $^{23}$

We require that subsidiaries in the control group have a foreign U.S.-listed GUO as U.S.-listed firms face a specific set of regulations. We do not include subsidiaries with nonU.S.-listed GUOs in the control group, as this would raise the concern that subsidiaries of U.S.listed-GUOs adjust earnings management practices following foreign PCAOB inspections in general, rather than due to the inspection of their GUO auditor. U.S.-listed firms differ from non-U.S.-listed firms as literature provides evidence that they tend to have higher accounting quality (see, e.g., Lang, Raedy, and Yetman, 2003).

We only include international subsidiaries in our control group. In doing so, we control for the possibility that international subsidiaries react differently to events at the GUO level than national subsidiaries. Additionally, literature provides evidence that international and national subsidiaries significantly differ with regard to earnings management practices and financial characteristics (see, e.g., Gill-de-Albornoz and Rusanescu, 2017; Gill-de-Albornoz et al., 2018).

We are interested in capturing the effect on treated subsidiaries in the year after the inspection. Therefore, we construct an indicator variable that equals one for the first year following the final report of the initial PCAOB inspection of a GUO's auditor, and zero otherwise (we call this variable POST_INSPECTION) (Krishnan et al., 2017; Chan et al., 2012). To analyze the effect of initial PCAOB inspections of GUO auditors on subsidiaries' earnings management, we estimate the following subsidiary-level regression:

\footnotetext{
${ }^{22}$ Note that we do not construct two-year windows for control subsidiaries. In untabulated robustness tests, we also construct two-year windows for control subsidiaries. The canon of our main results remains unchanged.

${ }^{23} \mathrm{We}$ cannot require subsidiaries in the control group to have same GUO-country and GUO-industry combinations as treated subsidiaries as this would reduce the sample size by $95 \%$. However, our fixed effects structure controls for GUO-country and group characteristics. We discuss consequences of these research design choices in Section 4.2 .
} 


$$
\begin{aligned}
\mid \text { DACC }_{s, t}= & \beta_{0}+\beta_{1} \text { INSPECTION }_{s}+\beta_{2} \text { POST_INSPECTION }_{s, t}+\text { CONTROLS }_{-} \\
& +F E+\varepsilon_{s, t}
\end{aligned}
$$

where $s$ and $t$ index subsidiaries and years. $|D A C C|_{s, t}$ describes the absolute discretionary accruals of subsidiary $s$ in year $t$, our measure of subsidiary earnings management (as discussed in Section 3.2 above). INSPECTION I $_{S}$ equals one for our treated sample of subsidiaries with an initial PCAOB inspection of the GUO auditor. POST_INSPECTION s.t $_{\text {e }}$ equals one for subsidiaries in the first year following the final report of the initial PCAOB inspection of their GUO's auditor, and zero otherwise. The coefficient of interest is $\beta_{2}$. It measures the treatment effect of initial PCAOB inspections at the GUO-auditor level on absolute discretionary accruals in the year after the inspection compared to all control observations. CONTROLS is a vector of control variables.

Prior studies document size, profitability, growth, previous loss years, financial structure, and operating risk as possible determinants of earnings management (Beuselinck et al., 2018; Krishnan et al., 2017; Fung et al., 2017). Hribar and Nichols (2007) argue that cash flow volatility and turnover volatility as measures for operating risk are crucial for the analysis of absolute discretionary accruals. We include the logarithm of total assets (SIZE), the absolute value of return on assets $(R O A)$, the absolute value of cash flow from operations scaled by total assets ( $C F O$ ), the percentage change in turnover compared to the previous year (TURNOVER_GROWTH), an indicator variable that equals one for years following a loss year (LOSS), total debt scaled by total assets (LEVERAGE), the standard deviation of the cash flow from operations $\left(S D_{-} C F O\right)$, and the standard deviation of turnover $\left(S D_{-} T U R N O V E R\right)$ as control variables. The Appendix contains detailed variable definitions.

$F E$ is a vector of fixed effects. It includes year, subsidiary-industry, subsidiary-country, and GUO-country or group fixed effects. Prior literature on earnings management in the international context applies year, industry, and country fixed effects to control for 
unobservable characteristics (Krishnan et al., 2017). In our setting, this translates into year, subsidiary-industry, and subsidiary-country fixed effects. As we analyze international subsidiaries with international ownership structures, we also include GUO-country or group fixed effects. First, we introduce GUO-country fixed effects to capture unobservable determinants of subsidiary earnings management arising from characteristics of the GUO country. Second, in our main regression model, we employ group fixed effects to control for unobservable characteristics within groups that could determine the earnings management of subsidiaries (Beuselinck et al., 2018). Group fixed effects include, but go beyond, a GUO's country. We follow Beuselinck et al. (2018) and apply two-way clustering of standard errors at the subsidiary-country and at the subsidiary-industry as subsidiaries in the same country and industry can share common characteristics.

\subsection{Sample Construction}

Our sample construction follows four major steps. First, we define 324 initial foreign PCAOB inspections of non-U.S. auditors between 2009 and 2016. Second, we determine 583 non-U.S. GUOs of multinational groups that are listed in the U.S. and for which Orbis allows to identify GUO-auditor data. To construct our treated sample, we combine these two datasets in step three. This results in 151 GUOs with 2,517 international subsidiaries that are affected by an initial PCAOB inspection of the GUO auditor. We allow initial PCAOB inspections of GUO auditors to trigger a subsidiary treatment only once in our sample period. If a subsidiary is defined as treated due to an initial PCAOB inspection of its GUO auditor, we do not define the same subsidiary as treated if the GUO replaces its auditor and the new auditor is initially PCAOB-inspected in a subsequent year. ${ }^{24}$ For our treatment sample, we construct a two-year window covering one year before and one year after the PCAOB inspection of the GUO auditor.

\footnotetext{
${ }^{24}$ Including observations where GUOs are affected by multiple initial PCAOB inspections of their auditors would dilute the effect of initial PCAOB inspections due to the experience and adjustments of these GUOs following recurring $\mathrm{PCAOB}$ inspections of their auditors.
} 
In step four, we construct our control group. To do so, we start with 27,199 international subsidiaries of groups with U.S.-listed GUOs and identifiable GUO-auditor data that did not have an initial PCAOB inspection of their GUO's auditor before 2017. We retain subsidiaryyear observations in the country-industry-year combinations of treated subsidiaries and drop treated observations for which no control observations are available. This ensures that when we compare the treated and control groups, international subsidiaries in both groups share characteristics that could be important determinants of earnings management. After dropping observations with missing data for our main analysis, we retain 744 subsidiary-year observations for the treated group and 2,815 subsidiary-year observations for our control group. This results in 3,559 subsidiary-year observations for our final sample.

In Table 1 Panel A, we present the distribution of subsidiary-year observations in the final sample across countries. Countries with the most observations are France $(26.95 \%$ of all observations), Italy (13.82\% of all observations), and the United Kingdom (10.51\% of all observations). Table 1 Panel B presents the distribution of GUOs across countries. The most important GUO countries (in terms of observations) are Japan (40.99\% of all observations), the United Kingdom (18.4\% of all observations), and Switzerland (14.02\% of all observations). In robustness tests, we exclude subsidiaries from major countries and subsidiaries with GUOs from major countries. ${ }^{25}$

\subsection{Descriptive Statistics}

We present descriptive statistics for the treated and control group as well as for the preand post-inspection year of the treated group in Table 2. All continuous variables are winsorized

\footnotetext{
${ }^{25}$ In prior studies (see, e.g., Shroff et al., 2014; Bena et al., 2019; Beuselinck et al., 2018), up to 55\% of the observations have a GUO from the U.S. As we analyze subsidiaries of foreign U.S.-listed GUOs, subsidiaries of U.S. GUOs are not in our sample. Due to missing public disclosure requirements for international subsidiaries located in the U.S., prior studies (see, e.g., Shroff et al., 2014; Bena et al., 2019; Beuselinck et al., 2018) include very few, if any, observations from international subsidiaries located in the U.S. in their samples (maximum $2.2 \%$ in Shroff et al., 2017). Therefore, the lack of international subsidiaries located in the U.S. in our sample is not surprising.
} 
at the upper and lower $1 \%$ level of their distributions. ${ }^{26}$ Panel A presents descriptive statistics for the treated and control sample. The mean of absolute discretionary accruals is similar for both groups. Subsidiaries in the treated and control samples are comparable regarding size, cash flow from operations, financial structure, and operating risk. Subsidiaries in the treated sample are slightly more profitable and grow less than subsidiaries in the control sample. Overall, the comparison demonstrates that subsidiaries in the control and treatment groups are similar with regard to important characteristics for the determination of earnings management.

We present descriptive statistics of the treated sample in the pre- and post-inspection year in Panel B of Table 2. The mean of absolute discretionary accruals decreases from the preto the post-inspection year with everything else except turnover growth remaining stable (turnover growth drops from the pre- to the post-inspection year). This could be an indicator for a decrease in earnings management of treated subsidiaries in the year after PCAOB inspections at the GUO-auditor level. To analyze this further, we include the control group and estimate regression (3). We present and discuss the results of these estimations in the next section.

\section{Results}

\subsection{Main Result}

We estimate regression (3) to test hypothesis $H 1$. As discussed above, treated firms are international subsidiaries of foreign U.S.-listed GUOs whose auditor is initially PCAOBinspected during our sample period. Control firms are international subsidiaries of foreign U.S.listed GUOs with no initial PCAOB inspection of their GUO auditors before or during our sample period. The subsidiary observations in the control group are required to be in the same

\footnotetext{
${ }^{26}$ Alternatively, we truncate all continuous variables at the upper and lower $1 \%$ level of their distributions in unreported analyses. The canon of our main results is unchanged.
} 
country-industry-year combinations as treated subsidiaries' observations. We present regression results in Table 3 .

The coefficient on POST_INSPECTION is significantly negative in model (1). It measures the effect of initial GUO-auditor level PCAOB inspections on absolute discretionary accruals in the year after the inspection compared to all control observations. Therefore, the estimate indicates a decrease in absolute discretionary accruals at international subsidiaries after PCAOB inspections of their GUO's auditor. This result leads us to reject hypothesis $H 1$ as the estimation documents a significant effect of initial PCAOB inspections concerning GUO auditors on earning management practices of international subsidiaries. Model (1) employs year, subsidiary-industry, subsidiary-country, and GUO-country fixed effects. This allows us to control for unobservable subsidiary-year, subsidiary-industry, subsidiary-country, and GUOcountry determinants of subsidiary-level earnings management. Prior literature on earnings management in the international context applies year, industry, and country fixed effects to control for unobservable factors (see, e.g., Krishnan et al., 2017). As Beuselinck et al. (2018) provide descriptive evidence for a correlation between GUO-country characteristics and international subsidiary earnings management, it is important to include GUO-country fixed effects due to the international ownership structures of the subsidiaries in our sample.

We next control for subsidiary characteristics in model (2). Even when controlling for subsidiary-level determinants of earnings management, the estimated coefficient on POST_INSPECTION still remains negative and significant with similar size as in model (1). Consequently, the effect indicated by model (1) does not seem to be brought about by subsidiary-level determinants of earnings management, as the coefficient on POST_INSPECTION is robust against the inclusion of subsidiary characteristics as control variables. Consistent with prior studies, the regression estimates document that subsidiaries that are smaller, have higher cash flows from operations, larger growth, prior losses, and higher 
operating risk tend to have higher absolute discretionary accruals (see, e.g., Beuselinck et al., 2018).

We replace GUO-country fixed effects by group fixed effects in model (3) and (4). Beuselinck et al. (2018) provide evidence for a correlation between group characteristics and international subsidiary earnings management. The coefficient on POST_INSPECTION remains negative and significant for the estimate in model (3) with no control variables. While GUO-country fixed effects only control for unobservable GUO-country characteristics, group fixed effects control for various time-invariant GUO level determinants of subsidiary earnings management. Even with these stricter fixed effects, the coefficient on POST_INSPECTION continues to be negative and significant with comparable size as in model (1).

The coefficient on POST_INSPECTION remains negative and significant with similar size if we include subsidiary characteristics as control variables in model (4). The coefficients of the control variables document similar results as in model (2), except for the insignificant coefficient of LOSS.

The estimated coefficient on POST_INSPECTION is significant at the 5\% level throughout all models. The coefficient ranges between -0.0683 and -0.0781 in the estimations of Table 3. The standard deviation of absolute discretionary accruals for treated subsidiaries in the pre-inspection period is 0.393 . Hence, the estimates indicate an average decline by $17.38 \%$ to $19.87 \%$ of the pre-inspection standard deviation in the post-inspection year, which implies not only a statistically but also an economically significant decrease in absolute discretionary accruals of international subsidiaries after initial PCAOB inspections of GUO auditors.

These results allow us to reject hypothesis $H 1$ as we find an economically and statistically significant effect of initial PCAOB inspections regarding auditors of foreign U.S.listed GUOs on international subsidiary earnings management. All four models in Table 3 document a decrease in absolute discretionary accruals compared to same country-industryyear observations of subsidiaries with non-U.S. GUOs that are also U.S.-listed but do not have 
a PCAOB-inspected auditor. Our findings suggest a transmission of PCAOB inspections within multinational business groups. We provide evidence for the cross-border influence of the PCAOB and show benefits for firms neither directly audited by the PCAOB-inspected accounting firms nor under the regulations assessed by the PCAOB during inspections. Additionally, we document a transmission effect of an event at the GUO level (i.e. initial PCAOB inspection of the GUO auditor) on the accounting discretion executed in international subsidiaries. This effect could arise from GUO-level pressure to adjust subsidiaries' earnings management with increased audit quality at the GUO level.

\subsection{Identification Analysis}

To empirically identify the effect of PCAOB inspections on international subsidiaries, our research design needs to mitigate the empirical concern of omitted variables.

Our control group construction and our fixed effects structure design aim to isolate the effect of an initial PCAOB inspection of the GUO auditor. We compare subsidiary earnings management in the year following an inspection of the GUO's auditor to subsidiary earnings management of control subsidiaries in the same years. We also require that the control subsidiary-observations are from the same industry and from the same country as the treated subsidiary-observations. Requiring control subsidiaries to be in the same subsidiary countries and subsidiary industries as treated subsidiaries ensures that differences at the subsidiarycountry and subsidiary-industry level (which could influence subsidiaries' reactions to GUOlevel events) do not drive our results. Similarly, requiring control observations from the same years as treated observations controls for possible time trends in the impact of GUO-level events on international subsidiaries.

In addition to the strict requirements for control observations, our empirical estimation also uses an extensive fixed effects structure. The fixed effects ensure that our results are not 
driven by unobservable variables specific to a subsidiary country, a subsidiary industry, a year, or a GUO country or group.

In spite of our control group and fixed effects, omitted variables that correlate with both PCAOB inspections and subsidiary earnings management could still raise concerns of alternative explanations for our results. The PCAOB could potentially consider GUO characteristics such as GUO earnings management incentives as red flags and, based on these, decide to inspect GUO auditors. Such GUO characteristics could correlate with subsidiary earnings management and hence give rise to an omitted variable bias.

We first note that PCAOB inspections primarily focus on auditors and their audit quality but not audit clients of these auditors. Therefore, a correlation between GUO characteristics and PCAOB inspections seems unlikely. Nevertheless, to further mitigate this concern, we consider (and try to control for) three types of GUO characteristics: time-invariant GUO characteristics, GUO earnings management incentives, and GUO characteristics potentially correlated with high subsidiary earnings management.

We control for time-invariant GUO characteristics by including group fixed effects in our main model. As long as time-invariant GUO characteristics could influence both the likelihood of an auditor's PCAOB inspection and subsidiary-level earnings management, these fixed effects control for the effect of such characteristics. Beuselinck et al. (2018) provide evidence for a correlation between time-varying GUO earnings management incentives and subsidiary earnings management. At the same time, one could argue that the PCAOB might consider earnings management incentives of audit clients for the selection of auditors that are inspected. Therefore, we control for GUO earnings management incentives in additional tests discussed in Section 4.4.1. The canon of our main result remains robust.

The significantly positive coefficient on INSPECTION in model (1), (2), and (4) of Table 3 could raise further concerns of omitted variables. This coefficient measures the difference in subsidiary earnings management between treated observations in the pre- 
inspection period and all control observations. The coefficient indicates higher subsidiary earnings management of treated firms prior to inspections. Should higher subsidiary earnings management be correlated with a GUO characteristic that could trigger an inspection of the GUO auditor, this could result in an omitted variable bias. To mitigate this concern, we perform an additional analysis with a propensity-score matched control sample matched on preinspection subsidiary earnings management, size, profitability, growth, previous loss years, financial structure, and operating risk. This construction aims to mitigate pre-inspection differences in subsidiary earnings management and its determinants between treated and control observations. To this end, we only keep nearest neighbors of treated subsidiaries and require that at least two potential matches are available. Unreported regression analyses estimate insignificant coefficients on INSPECTION and hence indicate no difference between preinspection subsidiary earnings management of treated subsidiaries and all control observations in the propensity-score matched sample. As coefficients on POST INSPECTION remain significantly negative, unreported estimates mitigate concerns regarding GUO characteristics that correlate with high pre-inspection subsidiary earnings management and trigger PCAOB inspections of GUO auditors.

Overall, our strict requirements for the control group, the use of a tight fixed effects structure, and the inclusion of control variables mitigate concerns regarding alternative explanations of our findings (i.e. non-initial GUO auditor-PCAOB inspection-related). For correlated omitted variables to still be a concern, time-variant GUO characteristics would have to be correlated with subsidiary earnings management and PCAOB inspection decisions, not be correlated with time-variant GUO earnings management incentives, and not be captured in our propensity-score matched sample. Therefore, we are confident that our research design is going some way towards allowing for a causal interpretation of the transmission effect of initial PCAOB inspections of GUO auditors on international subsidiaries. 


\subsection{Further Analysis}

Some countries prohibit PCAOB inspections of auditors located in their jurisdictions. Literature provides evidence that audit quality of U.S.-listed firms increases if PCAOB inspections are permitted (see, e.g., Lamoreaux, 2016; Song and Sun, 2017; He, Li, Liu, and Pittman, 2019). PCAOB access in a country could influence the reaction of a subsidiary to the initial PCAOB inspection of its GUO auditor. On the one hand, the effect on subsidiaries that are located in countries with PCAOB access could be larger due to a higher awareness of PCAOB inspections in the country. On the other hand, a larger effect could be expected for subsidiaries that are located in countries with no PCAOB access as firms' awareness of PCAOB inspections is low. A larger effect could arise from higher potential for improvements in these countries.

We define countries where PCAOB inspections are permitted or prohibited and replace POST_INSPECTION by POST_INSPECTION_X_ACCESS and POST_INSPECTION_X_NO_ACCESS to test this empirically. 27 POST_INSPECTION_X_ACCESS equals one for treated subsidiaries in the post-inspection year if the subsidiary country permits PCAOB inspections, and zero otherwise. Similarly, POST_INSPECTION_X_NO_ACCESS equals one for treated subsidiaries in the postinspection year if the subsidiary country prohibits PCAOB inspections, and zero otherwise.

Table 4 provides regression results. While model (1) presents regression results without control variables, we include control variables in model (2). The coefficient on POST_INSPECTION_X_ACCESS is negative and significant in both models. In model (1), the coefficient on POST_INSPECTION_X_NO_ACCESS is negative and significant, whereas it is positive and insignificant in model (2). These results indicate a larger effect on earnings management of subsidiaries that are located in countries with PCAOB access. This

\footnotetext{
${ }^{27}$ We obtain information on PCAOB access in countries from the official PCAOB website on international PCAOB inspections (https://pcaobus.org/International/Pages/default.aspx).
} 
interpretation is corroborated as the coefficients on POST_INSPECTION_X_ACCESS and POST_INSPECTION_X_NO_ACCESS are significantly different in both models (p-value (model (1)): 0.02, p-value (model (2)): 0.01). Moreover, the estimated negative coefficient on POST_INSPECTION_X_ACCESS is $15 \%$ stronger than in the comparable main model. The stronger effect in subsidiary countries that allow PCAOB access could be driven by higher awareness of PCAOB inspections in these countries compared to countries that do not allow PCAOB access. Due to this higher awareness, an inspection at the GUO-auditor level could result in stronger reactions.

\subsection{Robustness Tests}

\subsubsection{GUO Earnings Management Incentives}

Literature finds that GUO earnings management incentives can determine international subsidiary earnings management (see, e.g., Beuselinck et al., 2018). GUO earnings management incentives can be both observable and unobservable. Observable characteristics are "Big Four" GUO auditors, small gains at the GUO level, financial situations of the GUO, and differences in corporate tax rates between the subsidiary and GUO country. Unobservable differences between the GUO country and subsidiary country could correlate with GUO earnings management incentives. We extend our baseline model with control variables for these observable and unobservable characteristics.

First, firms audited by accounting firms of the "Big Four" group are less likely to engage in earnings management (see, e.g., Fung et al., 2017; Krishnan et al., 2017). Bishop, Hermanson, and Houston (2013) document that audit deficiencies are less likely for clients of "Big Four" auditors. Consequently, GUOs audited by "Big Four" accounting firms could influence subsidiary managers to adjust the degree of earnings management. We include the indicator variable GUO_BIG4_AUDITOR that is coded one if the GUO is audited by KPMG, 
PwC, Ernst \& Young, or Deloitte, and zero otherwise. ${ }^{28}$ Results are reported in model (1) of Table 5 Panel A. The coefficient on POST_INSPECTION remains significant and negative with similar size as in the baseline model. The coefficient on GUO_BIG4_AUDITOR is significantly negative, indicating a lower degree of subsidiary earnings management if GUOs are audited by "Big Four" auditors.

Second, Beuselinck et al. (2018) document a positive relation between GUO earnings management incentives related to the financial situation of the GUO and subsidiary earnings management. We include two measures to capture incentives of GUOs to influence subsidiary earnings management that are related to the financial situation of the GUO. First, firms reporting small gains are more likely to have managed earnings (see, e.g., Burgstahler and Dichev, 1997; Degeorge, Patel, and Zeckhauser, 1999). Hence, GUOs with small gains could influence subsidiary managers to increase earnings management with the intention to boost consolidated profits in the intended direction. Therefore, we construct the indicator variable GUO_SMALL_GAIN that is set to one if consolidated GUO net profits are lower than $1 \%$ of consolidated total assets. The second measure captures financial constraints of the GUO. Prior literature documents an increase in earnings management if firms face the requirement to finance operating activities with new capital. GUO_FIN_CONSTRAINTS is an indicator variable coded one if the GUO consolidated cash flow scaled by current assets at the beginning of the year is less than $-0.5 .^{29}$

We present the regression estimates with control variables for GUO earnings management incentives measured by small gains and financial constraints in models (2) and (3) of Table 5 Panel A. The coefficient on POST_INSPECTION remains negative and significant throughout both models. The coefficient on GUO_SMALL_GAIN is not significant. The

\footnotetext{
${ }^{28}$ We define all affiliates of "Big Four" firms as such auditors. This applies to different legal entities across countries, e.g. Ernst \& Young AG in Switzerland and Ernst \& Young S.L. in Spain, as well as to legal entities within a country, e.g. KPMG Audit Plc. and KPMG LLP in the UK.

${ }^{29}$ We follow Beuselinck et al. (2018) for the construction using Orbis and Beuselinck et al. (2018) and Degeorge et al. (1999) for the definition.
} 
coefficient on GUO_FIN_CONSTRAINTS is significant and positive, indicating a positive relation between GUO financial constraints and subsidiary earnings management.

Third, literature provides evidence that multinational business groups shift profits if corporate tax rates vary across countries of group members (see, e.g., Beer and Loeprick, 2013; De Simone, 2016). Hence, the difference in tax rates between the GUO country and the subsidiary country could determine GUO incentives to manage earnings of international subsidiaries. Therefore, we control for the difference in tax rates by $D_{-} T A X .^{30}$ Model (4) of Table 5 Panel A presents regression results controlling for the difference in tax rates. The coefficient on POST_INSPECTION remains significantly negative. The coefficient on D_TAX is not significant

We also include all observable GUO incentive variables (as discussed above) in one model and present results in model (5) of Table 5 Panel A. The coefficient on POST_INSPECTION remains negative and significant. These findings indicate that our main result does not seem to be driven by GUO earnings management incentives.

Finally, as we already control for group fixed effects in our baseline model, concerns regarding time-invariant unobservable GUO characteristics that could drive our results are mitigated. However, unobservable differences between the GUO country and the subsidiary country could correlate with GUO earnings management incentives. For instance, regulation differences between the GUO country and the subsidiary country could result in lower earnings management at the GUO level and higher earnings management at the subsidiary level, or vice versa. In untabulated robustness tests, we introduce subsidiary-GUO country-pair fixed effects to capture these unobservable differences between each subsidiary-country and GUO-country combination. The canon of our main results remain robust. In addition, prior studies suggest

\footnotetext{
30 We employ tax rates from the KPMG Corporate Tax Rates Table (https://home.kpmg.com/xx/en/ home/services/tax/tax-tools-and-resources/tax-rates-online/corporate-tax-rates-table.html) to construct the difference in corporate tax rates between GUO and subsidiary countries.
} 
that clients of PCAOB-inspected auditors increase investments and change their capital structure (Shroff, 2017). To test whether such changes drive our results, we interact leverage and investment measures of GUOs and subsidiaries with INSPECTION and POST_INSPECTION. Our result remains robust when we control for these interaction terms in untabulated robustness tests.

\subsubsection{Exclusion of Observations from Major Countries}

Table 1 presents the sample distribution across countries. While $27 \%$ of the observations are from subsidiaries located in France, the second most popular country in our sample is Italy (14\%). $41 \%$ of the subsidiary-year observations have a GUO from Japan, $18 \%$ from the United Kingdom. The distribution across subsidiary countries and GUO countries could raise concerns that individual countries where many subsidiaries or GUOs are located drive our findings. To mitigate this concern, we drop observations from the country with the most subsidiary-year observations (France) and show regression results in models (1) and (2) of Table 5 Panel B. We present results of the sample without subsidiary observations that have a GUO from the country with most GUOs (Japan) in models (3) and (4). The coefficient on POST_INSPECTION remains negative and significant with comparable size as in the main model if we exclude subsidiary-year observations from France (this procedure excludes $27 \%$ of observations). If we drop subsidiary-year observations with GUOs from Japan, the sample decreases by roughly 41\%. The coefficient on POST_INSPECTION still remains significantly negative, while the size of the indicated effect is slightly smaller than in our main model. ${ }^{31}$

Orbis collects financial information from various sources such as financial statement filings, securities commissions, and further data providers. This approach could induce an

\footnotetext{
${ }^{31}$ Alternatively, we exclude subsidiaries from Italy and GUOs from the United Kingdom in separate analyses. In addition, we exclude subsidiaries from both France and Italy as well as subsidiaries with GUOs from both Japan and the United Kingdom in separate analyses. The coefficient on POST_INSPECTION remains significantly negative throughout these tests.
} 
overrepresentation of countries requiring limited liability companies to file financial reports (e.g. European Union members), while countries that do not require filings of limited liability firms (e.g. Canada) could be underrepresented (Beuselinck et al., 2018). Consequently, a potential concern is that this approach influences the inferences of our findings as subsidiaries from countries that do not require limited liability companies to file financial reports could dilute the results. To mitigate this concern, we first only keep European subsidiaries in untabulated robustness tests. Second, we also require that their GUOs are European. Alternatively, we exclude subsidiaries from Canada or subsidiaries with GUOs from Canada in untabulated analyses. ${ }^{32}$ The canon of our main analysis remains robust throughout these tests.

\subsubsection{Validation of Earnings Management Measure}

Chen, Hribar, and Melessa (2018) raise concerns related to two-stage regressions that use residuals as dependent variables. As we construct our earnings management proxy by using a two-stage regression approach, their concerns also apply to the construction of our measure. To mitigate the concern that our design generates biased coefficients, we follow Chen et al. (2018) and include the control variables applied in the first-stage regression to determine discretionary accruals from residuals (regression (1)) in the second-stage regression (regression (3)). We do not include the control variable for total assets as we already control for size in the baseline regression. Regression results are presented in model (1) of Table 5 Panel C. The coefficient on POST_INSPECTION remains negative and significant.

For our main earnings management measure, we pool regressions to determine residuals that proxy for discretionary accruals across years and subsidiary industries, where industries are defined by the primary two-digit NACE Rev. 2 code. To test our baseline definition of

\footnotetext{
32 This approach also mitigates concerns regarding Canada's proximity to the U.S. that could result in higher awareness of the PCAOB in Canada than in other countries. As our result is robust against excluding subsidiaries from Canada or subsidiaries with Canadian GUOs, the danger that these subsidiaries drive our results through a larger effect of inspections resulting from higher PCAOB awareness, is limited.
} 
earnings management, we alternatively pool regressions across years, subsidiary industries, and subsidiary countries $\left(\left|D A C C_{C}\right|\right)$. We define industries by the primary NACE Rev. 2 section for this approach. We follow Beuselinck et al. (2018) by decreasing the number of industry clusters. ${ }^{33}$ The choice of whether to pool regressions across subsidiary countries is a trade-off between capturing country characteristics and considering a low number of firms for the estimation regressions. Through the application of a broader industry classification, the approach captures country characteristics while the cost of losing observations from countryindustry groups is decreased. Regression results are presented in model (2) of Table 5 Panel C. The coefficient on POST_INSPECTION continues to be significantly negative. Note that we classify subsidiary industries by the primary NACE Rev. 2 section for fixed effects and standard error clustering in model (2), according to the different earnings management construction.

\section{Conclusion}

Prior studies document an improvement in audit quality after initial international PCAOB inspections of auditors (see, e.g., Krishnan et al., 2017). However, it is unclear if this improvement transmits through multinational business groups. Our study investigates the effect of an initial GUO-auditor PCAOB inspection on international subsidiaries. Our results provide evidence of a decrease in earnings management of international subsidiaries in years following the initial PCAOB inspection of their U.S.-listed GUO's non-U.S. auditor. In doing so, we also document an additional dimension of international benefits arising from foreign PCAOB inspections. Fung et al. (2017) document an improvement in audit quality for non-U.S.-listed public firms following the initial PCAOB inspection of their non-U.S. auditor. Our findings

\footnotetext{
${ }^{33}$ Beuselinck et al. (2018) apply the Campbell (1996) industry classification. As we define subsidiary industries by NACE codes, we cannot adopt the Campbell (1996) twelve industries that are defined based on SIC codes. Therefore, we classify industries by their primary NACE Rev. 2 sections. This results in 21 different industry classifications.
} 
provide evidence for international benefits of foreign PCAOB inspections beyond the country of the inspected auditor.

An advantage of our research setting is the staggered nature of initial international PCAOB inspections over years, countries, and auditors. Additionally, we require our control group to share various crucial characteristics with treated subsidiaries and control for subsidiary and GUO characteristics that determine earnings management by using control variables and a strict fixed effects structure. These research design choices thus mitigate concerns of contemporaneous events driving our results.

While prior research documents an improvement in audit quality for clients after initial PCAOB inspections, we argue that the effect on international subsidiary earnings management is not obvious. International subsidiaries are not the primary target of foreign PCAOB inspections, as inspections focus on auditors of U.S.-listed firms and aim to improve audit quality of U.S.-listed companies. Hence, it is a priori unclear if GUOs shift earnings management to international subsidiaries or if GUOs require international subsidiaries to adjust earnings management policies with the increased audit quality at the consolidated accounts level.

One caveat to note is that we cannot require subsidiaries in the control group to have GUOs from the same country and industry as treated subsidiaries. This requirement would decrease the sample size by roughly $95 \%$. However, our tight control group construction, our strict fixed effects structure, and the PCAOB inspection schedule mitigate the concern of alternative explanations of our results arising from this design choice. Our findings suggest that foreign PCAOB inspections have benefits over and above the positive effects on financial statements of U.S.-listed and non-U.S.-listed firms that are audited by inspected audit firms and located in the country of inspected auditors. The results are of potential interest to the PCAOB and national regulators as we document international benefits of foreign PCAOB inspections across borders. 


\section{References}

Abbott, L., Gunny, K., Zhang, T., 2013. When the PCAOB Talks, Who Listens? Evidence from Client Firm Reaction to Adverse, GAAP-Deficient PCAOB Inspection Reports. Auditing: A Journal of Practice \& Theory 32, 1-31.

Ali, A., Zhang, W., 2015. CEO Tenure and Earnings Management. Journal of Accounting and Economics 59, 60-79.

Allee, K. D., Deangelis, M. D., 2015. The Structure of Voluntary Disclosure Narratives: Evidence from Tone Dispersion. Journal of Accounting Research 53, 241-74.

Alfaro, L., Chen, M. X., 2018. Selection and Market Reallocation: Productivity Gains from Multinational Production. American Economic Journal: Economic Policy 10, 1-38.

Aylmer, R. J., 1970. Who Makes Marketing Decisions in the Multinational Firm? The Journal of Marketing 13, 25-30.

Beaver, W. H., Cascino, S., Correia, M., McNichols, M. F., 2019. Group Affiliation and Default Prediction. Management Science, forthcoming.

Bena, J., Dinc, S., Erdel, I., 2019. The International Transmission of Negative Shocks Through Multinational Companies: The Real Economy Channel. Unpublished working paper. Fisher College of Business Working Paper Series.

Beuselinck, C., Cascino, S., Deloof, M., Vanstraelen, A., 2018. Earnings Management within Multinational Corporations. The Accounting Review, forthcoming.

Bishop, C. C., Hermanson, D. R., Houston, R. W., 2013. PCAOB Inspections of International Audit Firms: Initial Evidence. International Journal of Auditing 17, 1-18.

Boone, J., Khurana, I., Raman, K., 2015. Did the 2007 PCAOB Disciplinary Order Against Deloitte Impose Actual Costs on the Firm or Improve its Audit Quality? The Accounting Review 90, 405-441.

Burgstahler, D., Dichev. I., 1997. Earnings Management to Avoid Earnings Decreases and Losses. Journal of Accounting and Economics 24, 99-126.

Campbell, J., 1996. Understanding Risk and Return. Journal of Political Economy 104, 298345.

Carcello, J. V., Carver, B. T., Neal, T. L., 2011. Market Reaction to the PCAOB's Inability to Conduct Foreign Inspections. Unpublished working paper. University of Tennessee.

Carcello, J. V., Hollingsworth, C., Mastrolia, S. A., 2011. The Effect of PCAOB Inspections on Big 4 Audit Quality. Research in Accounting Regulation. 23, 85-96.

Carson, E., Simnett, R., Thuerheimer, U., Vanstraelen, A., 2017. The Effect of National Inspection Regimes on Audit Quality. Unpublished working paper. UNSW Sydney, Maastricht University.

Carson, E., Simnett, R., Thuerheimer, U., Vanstraelen, A., Trompeter, G., 2018. Determinants and Consequences of Use of Component Auditors in Multinational Group Audits. Unpublished working paper. UNSW Sydney, Maastricht University, University of Central Florida.

Chan, L. H., Chen, K. C. W., Chen, T. Y., Yu, Y., 2012. The Effects of Firm-Initiated Clawback Provisions on Earnings Quality and Auditor Behavior. Journal of Accounting and Economics 54, 180-196.

Chaney, P., Faccio, M., Parsley, D., 2011, The Quality of Accounting Information in Politically Connected Firms. Journal of Accounting and Economics 51, 58-76.

Chen, B., Conaway, J., 2019. The Valuation Impact of PCAOB International Inspections on U.S. Multinational Corporations. Unpublished working paper. Boston University, George Mason University.

Chen, W., Hribar, P., Melessa, P., 2018. Incorrect Inferences when Using Residuals as Dependent Variables. Journal of Accounting Research 56, 751-796. 
Cravino, C., Levchenko, A., 2017. Multinational Firms and International Business Cycle Transmission. The Quarterly Journal of Economics 132, 921-962.

De Simone, L., 2016. Does a Common Set of Accounting Standards Affect Tax-Motivated Income Shifting for Multinational Firms? Journal of Accounting and Economics 61, 145 165.

De Simone, L., Klassen, K. J., Seidman, J. K., 2017. Unprofitable Affiliates and Income Shifting Behaviour. The Accounting Review 92, 113-136.

Dechow, P. M., Sloan, R., Sweeney, A., 1995. Detecting Earnings Management. The Accounting Review 70, 193-225.

Defond, M. L., Lennox, C. S., 2011. The Effect of SOX on Small Auditor Exits and Audit Quality. Journal of Accounting and Economics 52, 21-40.

Defond, M. L., Lennox, C. S., 2017. Do PCAOB Inspections Improve the Quality of Internal Control Audits? Journal of Accounting Research 55, 591-627.

Degeorge, F., Patel, J., Zeckhauser, R., 1999. Earnings Management to Exceed Thresholds. Journal of Business 72, 1-35.

Di Giovanni, Levchenko, A. A., Mejean, I., 2018. The Micro Origins of International BusinessCycle Comovement. American Economic Review 108, 82-108.

Dyreng, S. D., Hanlon, M., Maydew, E. L., 2012. Where do Firms Manage Earnings? Review of Accounting Studies 17, 649-687.

Fung, S. Y. K., Raman, K. K., Zhu, X., 2017. Does the PCAOB International Inspection Program Improve Audit Quality for Non-US Listed Foreign Clients? Journal of Accounting and Economics 64, 15-36.

Gill-de-Albornoz, B., Rusanescu, S., 2017. Foreign Ownership and Financial Reporting Quality in Private Subsidiaries. REFC - Spanish Journal of Finance and Accounting 47, 181-213.

Gill-de-Albornoz, B., Moreira, J. A. C., Rusanescu, S., 2018. Foreign Ownership and Financial Performance: Evidence from Private Subsidiaries. Unpublished working paper. Jaume I University, University of Porto, University of Groningen.

Gipper, B., Leuz, C., Maffett, M. G., 2019. Public Audit Oversight and Reporting Credibility: Evidence from the PCAOB Inspection Regime. Unpublished working paper. ECGI Finance Working Paper No. 453/2015, Chicago Booth Research Paper No. 15-40.

Gramling, A. A., Krishnan, J., Zhang, Y., 2011. Are PCAOB-Identified Audit Deficiencies Associated with a Change in Reporting Decisions of Triennially Inspected Audit Firms? Auditing: A Journal of Practice \& Theory 30, 59-79.

Gunny, K., Zhang, T., 2013. PCAOB Inspection Reports and Audit Quality. Journal of Accounting and Public Policy 32, 136-160.

He, Y., Li, B., Liu, Z., Pittman, J., 2019. Does the Threat of a PCAOB Inspection Mitigate U.S. Institutional Investors' Home Bias? Unpublished working paper. City University of Hong Kong, Hong Kong Baptist University, Memorial University of Newfoundland.

Hopland, A. O., Lisowsky, P., Mardan, M., Schindler, D., 2018. Flexibility in Income Shifting under Losses. The Accounting Review 93, 163-183.

Hribar, P., Collins, D. W., 2002. Errors in Estimating Accruals: Implications for Empirical Research. Journal of Accounting Research 40, 105-134.

Hribar, P., Nichols, C., 2007. The Use of Unsigned Earnings Quality Measures in Tests of Earnings Management. Journal of Accounting Research, 1017-1053.

Im, K., Mauldin, E., Patro, S., 2014. Outside Directors and Board Advising and Monitoring Performance. Journal of Accounting and Economics 57, 110-31.

Kalemli-Ozcan, S., Sorensen, B., Villegas-Sanchez, C., Volosovych, V., Yesiltas, S., 2015. How to Construct Nationally Representative Firm Level Data from the ORBIS Global Database. Unpublished working paper. NBER Working Paper No. 21558.

Klaasen, K. J., Lisowsky, P., Mescall, D., 2016. Transfer Pricing: Strategies, Practices, and Tax Minimization. Contemporary Accounting Research 34, 455-493. 
Kothari, S. P., Leone, A., Wasley, C., 2005. Performance Matched Discretionary Accrual Measures. Journal of Accounting and Economics 39, 163-197.

Krishnan, J., Krishnan, J., Song, H., 2017. PCAOB International Inspections and Audit Quality. The Accounting Review 93, 143-166.

Lamoreaux, P. T., 2016. Does PCAOB Inspection Access Improve Audit Quality? An Examination of Foreign Firms Listed in the United States. Journal of Accounting and Economics 61, 313-337.

Lang, M., Ready, J., Yetman, M., 2003. How Representative are Firms That are Cross-Listed in the United States? An Analysis of Accounting Quality. Journal of Accounting Research 41, 363-386.

Messier, J. W. F., Reynolds, J. K., Simon, C. A., Wood, D. A., 2011. The Effect of Using the Internal Audit Function as a Management Training Ground on the External Auditor's Reliance Decision. The Accounting Review 86, 2131-54.

Robinson, L. A., Stocken, P. C., 2013. Location of Decision Rights Within Multinational Firms. Journal of Accounting Research 51, 1261-1297.

Shroff, N., 2017. Does Auditor Regulatory Oversight Affect Corporate Financing and Investment Decisions? Unpublished working paper. Massachusetts Institute of Technology.

Shroff, N., Verdi, R. S., Yu, G., 2014. International Environment and the Investment Decisions of Multinational Corporations. The Accounting Review 89, 759-790.

Song, F. M., Sun, Z., 2017. One Firm and Two Regulators: The Role of PCAOB Cooperation in Cross-Listing Auditing. Unpublished working paper. The University of Hong Kong, Xiamen University.

Tweedle, J., 2018. Correlated Shocks Within Firms. Economics Letters 163, 95-97. 
Appendix

Variable Definitions

Variable

$\underline{\text { Main Variables }}$

|DACC |

INSPECTION

POST_INSPECTION

\section{$\underline{\text { Control Variables }}$}

SIZE

$R O A$

CFO
Definition

Sources

Absolute value of discretionary

Orbis, IMF

accruals measured by a World performance-adjusted modified Economic

Jones model (Dechow et al., Outlook 1995; Kothari et al., 2005), pooled across industries (primary two-digit NACE Rev. 2 codes) and years.

Indicator variable set to one if the auditor of the GUO is PCAOBinspected in the sample period (treatment group), zero otherwise.

Indicator variable set to one in the year following a PCAOB inspection (treatment group) of the GUO auditor, zero otherwise.

Orbis, PCAOB official website

Orbis, PCAOB official website

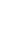

Natural logarithm of total assets. Orbis

Return on assets, measured as the Orbis absolute value of net income before extraordinary items scaled by total assets. If Orbis provides no information on extraordinary items, we assume an amount of zero.

Cash flow from operations, Orbis measured as the absolute value of the delta between net income before extraordinary items and total accruals scaled by total assets. If Orbis provides no information on extraordinary items, we assume an amount of zero. 


\section{Appendix (continued)}

Variable

$\underline{\text { Control Variables (continued) }}$

TURNOVER_GROWTH

LOSS

LEVERAGE

SD_CFO

SD_TURNOVER

$\underline{\text { Additional Variables }}$

GUO_BIG4_AUDITOR

GUO_SMALL_GAIN

GUO_FIN_CONSTRAINTS

D_TAX
Definition

\section{Sources}

Percentage change in turnover from Orbis year $t-1$ to $t$.

Indicator variable set to one if the Orbis subsidiary generated a loss in the previous year.

Leverage measured as total debt Orbis (long-term debt and short-term debt) scaled by total assets.

Standard deviation of cash flow Orbis from operations of the previous three years.

Standard deviation of turnover of Orbis the previous three years.

Indicator variable set to one for Orbis subsidiaries with a GUO that is audited by KPMG, PwC, Ernst \& Young, or Deloitte, zero otherwise.

Indicator variable set to one if the GUO reports a net profit in the consolidated financial statement that is less than $1 \%$ of total assets, zero otherwise.

Indicator variable set to one if the Orbis ratio of GUO consolidated cash flow and current assets at the beginning of the year is less than 0.5 .

Difference in the corporate tax rate $\mathrm{KPMG}$ between the GUO and subsidiary Corporate Tax country.
Orbis

Rates Table 


\section{Appendix (continued)}

Variable

$\underline{\text { Additional Variables (continued) }}$

REV_REC_TA

L ROA

L_INFLATION

L_GDP_GROWTH

$|D A C C c|$

POST_INSPECTION_X_ACCESS

POST_INSPECTION_X_NO_ACCESS
Definition

Sources

Difference between the change in Orbis

revenues and receivables from year $t-1$ to $t$ scaled by total assets.

Return on Assets in year $t-1$. Orbis

Inflation in year $t-1 . \quad$ IMF World

Economic

Outlook

Change in real purchasing power IMF World

based GDP from year $t-2$ to $t-1$. Economic

Outlook

Absolute discretionary accruals measured by a performanceadjusted modified Jones model (Dechow et al., 1995; Kothari et al., 2005), pooled across countries, industries (NACE Rev. 2 sections) and years.

Indicator variable set to one in PCAOB years following a PCAOB official inspection (treatment group) of website the GUO auditor if the country of the international subsidiary permits PCAOB inspections, zero otherwise.

Indicator variable set to one in PCAOB years following a PCAOB official inspection (treatment group) of website the GUO auditor if the country of the international subsidiary prohibits PCAOB inspections, zero otherwise.
Orbis, IMF

World

Economic

Outlook 
Table 1

Sample Distribution across Countries

$\underline{\text { Panel A: Distribution of Subsidiaries across Countries }}$

\begin{tabular}{lcc} 
Country & Subsidiary-Year Observations & $\mathbf{\%}$ \\
\hline Australia & 32 & 0.90 \\
Austria & 13 & 0.37 \\
Belgium & 246 & 6.91 \\
Bulgaria & 16 & 0.45 \\
Croatia & 18 & 0.51 \\
Czech Republic & 74 & 2.08 \\
Finland & 22 & 0.62 \\
France & 959 & 26.95 \\
Germany & 257 & 7.22 \\
Greece & 37 & 1.04 \\
Hungary & 29 & 0.81 \\
India & 65 & 1.83 \\
Ireland & 12 & 0.34 \\
Italy & 492 & 13.82 \\
Korea (Republic of) & 150 & 4.21 \\
Morocco & 8 & 0.22 \\
Norway & 138 & 3.88 \\
Philippines & 8 & 0.22 \\
Poland & 10 & 0.28 \\
Portugal & 80 & 2.25 \\
Romania & 23 & 0.65 \\
Serbia & 7 & 0.20 \\
Slovakia & 38 & 1.07 \\
Slovenia & 21 & 0.59 \\
Spain & 346 & 9.72 \\
Sweden & 37459 & 10.51 \\
United Kingdom & & \\
\hline Total & 36.00
\end{tabular}


Table 1 (continued)

$\underline{\text { Panel B: Distribution of GUOs across Countries }}$

\begin{tabular}{lcc} 
Country & Subsidiary-Year Observations & \% \\
\hline Australia & 30 & 0.84 \\
Austria & 6 & 0.17 \\
Canada & 298 & 8.37 \\
China & 7 & 0.2 \\
Finland & 101 & 2.84 \\
France & 67 & 1.88 \\
Ireland & 63 & 1.77 \\
Israel & 66 & 1.85 \\
Italy & 12 & 0.34 \\
Japan & 1,459 & 40.99 \\
Luxembourg & 12 & 0.34 \\
Netherlands & 149 & 4.19 \\
Singapore & 4 & 0.11 \\
South Africa & 31 & 0.87 \\
Spain & 44 & 1.24 \\
Sweden & 56 & 1.57 \\
Switzerland & 499 & 14.02 \\
United Kingdom & 655 & 18.40 \\
\hline Total & 3,559 & 100.00
\end{tabular}

Table 1 shows the distribution of subsidiary countries and GUO countries of the subsidiary-year observations in the final sample. International subsidiaries are treated if the auditor of their foreign U.S.-listed GUO is initially PCAOB-inspected during our sample period. We retain observations of international subsidiaries for the control group if they are in the country-industry-year combinations of treated observations. We require control subsidiaries to have a foreign U.S.-listed GUO whose auditor is not initially PCAOB-inspected before or during our sample period. We define a GUO as firm that directly or indirectly holds at least $50.01 \%$ in a subsidiary and is itself not owned by a single corporate shareholder by more than $25 \%$ or by a single non-corporate shareholder by more than $50 \%$. The GUOs of subsidiaries in our sample are U.S.-listed but not located in the U.S. Table 1 Panel A presents the distribution of subsidiary countries of the subsidiary-year observations. Table 1 Panel B presents the distribution of GUO countries of the subsidiary-year observations. 
Table 2

Descriptive Statistics

$\underline{\text { Panel A: Descriptive Statistics of Treated and Control Subsidiaries }}$

\begin{tabular}{lccccccc} 
& \multicolumn{3}{c}{ Treated } & & \multicolumn{3}{c}{ Control } \\
\cline { 2 - 3 } \cline { 7 - 8 } Variable & N & Mean & Std. Dev. & & N & Mean & Std. Dev. \\
\hline$|D A C C|$ & 744 & 0.2111 & 0.3302 & & 2,815 & 0.2074 & 0.2968 \\
SIZE & 744 & 10.3642 & 1.8913 & & 2,815 & 9.9763 & 1.8898 \\
ROA & 744 & 0.0884 & 0.1161 & & 2,815 & 0.0996 & 0.1296 \\
CFO & 744 & 0.1789 & 0.2100 & & 2,815 & 0.1854 & 0.2244 \\
TURNOVER_GROWTH & 744 & 0.0675 & 0.4811 & & 2,815 & 0.0811 & 0.4817 \\
LOSS & 744 & 0.2460 & 0.4309 & & 2,815 & 0.2348 & 0.4240 \\
LEVERAGE & 744 & 0.3090 & 0.2936 & & 2,815 & 0.2799 & 0.2782 \\
SD_CFO & 744 & 0.2451 & 0.2610 & & 2,815 & 0.2264 & 0.2245 \\
SD_TURNOVER & 744 & 0.4959 & 0.6106 & & 2,815 & 0.5086 & 0.6398
\end{tabular}


Table 2 (continued)

Panel B: Descriptive Statistics of Treated Subsidiaries in the Pre- and Post-Inspection Period

\begin{tabular}{lccccccc} 
& \multicolumn{3}{c}{ Pre-Inspection } & & \multicolumn{3}{c}{ Post-Inspection } \\
\cline { 2 - 4 } \cline { 7 - 9 } Variable & N & Mean & Std. Dev. & & N & Mean & Std. Dev. \\
\hline$|D A C C|$ & 372 & 0.2483 & 0.3930 & & 372 & 0.1740 & 0.2473 \\
SIZE & 372 & 10.3837 & 1.8699 & & 372 & 10.3447 & 1.9147 \\
ROA & 372 & 0.0882 & 0.1123 & & 372 & 0.0885 & 0.1200 \\
CFO & 372 & 0.1871 & 0.2100 & & 372 & 0.1707 & 0.2099 \\
TURNOVER_GROWTH & 372 & 0.0903 & 0.5341 & & 372 & 0.0447 & 0.4211 \\
LOSS & 372 & 0.2608 & 0.4396 & & 372 & 0.2312 & 0.4222 \\
LEVERAGE & 372 & 0.3169 & 0.2878 & & 372 & 0.3012 & 0.2995 \\
SD_CFO & 372 & 0.2401 & 0.2671 & & 372 & 0.2501 & 0.2551 \\
SD_TURNOVER & 372 & 0.4722 & 0.5536 & & 372 & 0.5196 & 0.6627
\end{tabular}

Table 2 presents descriptive statistics. International subsidiaries are treated if the auditor of their foreign U.S.listed GUO is initially PCAOB-inspected during our sample period. We retain observations of international subsidiaries for the control group if they are in the country-industry-year combinations of treated observations. We require control subsidiaries to have a foreign U.S.-listed GUO whose auditor is not initially PCAOB-inspected before or during our sample period. $|D A C C|$ denotes the absolute value of discretionary accruals. SIZE denotes the natural logarithm of total assets. ROA measures the absolute value of return on assets, $C F O$ the absolute value of cash flow from operations scaled by total assets, and TURNOVER_GROWTH the percentage change in turnover compared to the previous year. LOSS is an indicator variable that equals one for years following a loss year. LEVERAGE denotes the ratio of total debt scaled by total assets. SD_CFO and SD_TURNOVER denote the standard deviation of the cash flow from operations and turnover. Table 2 Panel A presents descriptive statistics of treated and control subsidiaries. Table 2 Panel B shows descriptive statistics of treated subsidiaries in the preinspection and post-inspection period. All continuous variables are winsorized at the upper and lower $1 \%$ level of their distributions. 
Table 3

Absolute Discretionary Accruals Regression

\begin{tabular}{|c|c|c|c|c|}
\hline & $\begin{array}{c}(1) \\
|D A C C|\end{array}$ & $\begin{array}{c}(2) \\
|D A C C|\end{array}$ & $\begin{array}{c}(3) \\
|D A C C|\end{array}$ & $\begin{array}{c}(4) \\
|D A C C|\end{array}$ \\
\hline INSPECTION & $\begin{array}{c}0.0288^{* *} \\
(2.240)\end{array}$ & $\begin{array}{c}0.0418^{* *} \\
(2.393)\end{array}$ & $\begin{array}{l}0.0296 \\
(0.997)\end{array}$ & $\begin{array}{c}0.0702 * * \\
(2.171)\end{array}$ \\
\hline POST_INSPECTION & $\begin{array}{c}-0.0781 * * \\
(-2.335)\end{array}$ & $\begin{array}{c}-0.0756 * * \\
(-2.236)\end{array}$ & $\begin{array}{c}-0.0736 * * \\
(-2.333)\end{array}$ & $\begin{array}{c}-0.0683 * * \\
(-2.079)\end{array}$ \\
\hline SIZE & & $\begin{array}{c}-0.00770 * * * \\
(-3.146)\end{array}$ & & $\begin{array}{c}-0.00995 * * * \\
(-2.870)\end{array}$ \\
\hline$R O A$ & & $\begin{array}{l}-0.0427 \\
(-0.436)\end{array}$ & & $\begin{array}{l}-0.0941 \\
(-1.378)\end{array}$ \\
\hline CFO & & $\begin{array}{c}0.512 * * * \\
(17.13)\end{array}$ & & $\begin{array}{c}0.529 * * * \\
(15.99)\end{array}$ \\
\hline TURNOVER_GROWTH & & $\begin{array}{c}0.107 * * * \\
(6.481)\end{array}$ & & $\begin{array}{c}0.104 * * * \\
(5.901)\end{array}$ \\
\hline$L O S S$ & & $\begin{array}{c}0.0270 * \\
(1.716)\end{array}$ & & $\begin{array}{l}0.0251 \\
(1.288)\end{array}$ \\
\hline LEVERAGE & & $\begin{array}{c}0.00447 \\
(0.171)\end{array}$ & & $\begin{array}{l}0.0201 \\
(0.715)\end{array}$ \\
\hline$S D_{-} C F O$ & & $\begin{array}{c}0.142 * * * \\
(6.538)\end{array}$ & & $\begin{array}{c}0.159 * * * \\
(5.094)\end{array}$ \\
\hline SD_TURNOVER & & $\begin{array}{c}0.0289 * * * \\
(2.792)\end{array}$ & & $\begin{array}{l}0.0200 * \\
(1.793)\end{array}$ \\
\hline Observations & 3,559 & 3,559 & 3,559 & 3,559 \\
\hline R-squared & 0.133 & 0.358 & 0.211 & 0.413 \\
\hline Year FE & Yes & Yes & Yes & Yes \\
\hline Subsidiary-Industry FE & Yes & Yes & Yes & Yes \\
\hline Subsidiary-Country FE & Yes & Yes & Yes & Yes \\
\hline GUO-Country FE & Yes & Yes & No & No \\
\hline Group FE & No & No & Yes & Yes \\
\hline SE Clustering & \multicolumn{4}{|c|}{ Subsidiary-Country \& Subsidiary-Industry } \\
\hline
\end{tabular}

Table 3 presents the estimates of the regressions on absolute discretionary accruals $(|D A C C|)$. International subsidiaries are treated if the auditor of their foreign U.S.-listed GUO is initially PCAOB-inspected during our sample period. We retain observations of international subsidiaries for the control group if they are in the countryindustry-year combinations of treated observations. We require control subsidiaries to have a foreign U.S.-listed GUO whose auditor is not initially PCAOB-inspected before or during our sample period. INSPECTION equals one for our treated sample of subsidiaries with an initial PCAOB inspection of their GUO auditor, and zero otherwise. POST_INSPECTION equals one for the first year following the final report year of the initial PCAOB inspection of a GUO's auditor, and zero otherwise. SIZE denotes the natural logarithm of total assets. ROA measures the absolute value of return on assets, $C F O$ the absolute value of cash flow from operations scaled by total assets, and TURNOVER_GROWTH the percentage change in turnover compared to the previous year. LOSS is an indicator variable that equals one for years following a loss year. LEVERAGE denotes the ratio of total debt scaled by total assets. SD_CFO and SD_TURNOVER denote the standard deviation of the cash flow from operations and turnover. $\overline{\mathrm{W}} \mathrm{e}$ include year, subsidiary-industry (primary two-digit NACE Rev. 2 codes), and subsidiary-country fixed effects in all models. Additionally, models (1) and (2) employ GUO-country fixed effects 
and models (3) and (4) group fixed effects. Standard errors are clustered at the subsidiary-country and subsidiaryindustry level. All continuous variables are winsorized at the upper and lower $1 \%$ level of their distributions. $t$ statistics are presented in parentheses and calculated based on robust standard errors. *,**, and *** represent significance at the $10 \%, 5 \%$, and $1 \%$ level, respectively. 
Table 4

Further Analysis: PCAOB Access in Subsidiary Countries

\begin{tabular}{|c|c|c|}
\hline & $\begin{array}{c}(1) \\
|D A C C|\end{array}$ & $\begin{array}{c}(2) \\
|D A C C|\end{array}$ \\
\hline INSPECTION & $\begin{array}{l}0.0299 \\
(1.001)\end{array}$ & $\begin{array}{c}0.0706^{* *} \\
(2.201)\end{array}$ \\
\hline POST_INSPECTION_X_ACCESS & $\begin{array}{c}-0.0819 * * \\
(-2.387)\end{array}$ & $\begin{array}{c}-0.0786 * * \\
(-2.255)\end{array}$ \\
\hline POST_INSPECTION_X_NO_ACCESS & $\begin{array}{l}-0.0128^{*} \\
(-1.962)\end{array}$ & $\begin{array}{c}0.00676 \\
(0.553)\end{array}$ \\
\hline SIZE & & $\begin{array}{c}-0.0101^{* * *} \\
(-2.916)\end{array}$ \\
\hline$R O A$ & & $\begin{array}{l}-0.0959 \\
(-1.421)\end{array}$ \\
\hline CFO & & $\begin{array}{c}0.529 * * * \\
(16.00)\end{array}$ \\
\hline TURNOVER_GROWTH & & $\begin{array}{c}0.104 * * * \\
(5.932)\end{array}$ \\
\hline LOSS & & $\begin{array}{l}0.0252 \\
(1.230)\end{array}$ \\
\hline LEVERAGE & & $\begin{array}{l}0.0200 \\
(0.706)\end{array}$ \\
\hline$S D_{-} C F O$ & & $\begin{array}{c}0.159 * * * \\
(5.141)\end{array}$ \\
\hline SD_TURNOVER & & $\begin{array}{l}0.0198 * \\
(1.795)\end{array}$ \\
\hline Observations & 3,559 & 3,559 \\
\hline R-squared & 0.211 & 0.413 \\
\hline Year FE & \multicolumn{2}{|c|}{ Yes } \\
\hline Subsidiary-Industry FE & \multicolumn{2}{|c|}{ Yes } \\
\hline Subsidiary-Country FE & \multicolumn{2}{|c|}{ Yes } \\
\hline $\begin{array}{l}\text { Group FE } \\
\text { SE Clustering }\end{array}$ & \multicolumn{2}{|l|}{$\begin{array}{l}\text { Subsidiar } \\
\text { Subsidia }\end{array}$} \\
\hline
\end{tabular}

Model (1): Test for differences POST_INSPECTION_X_ACCESS \& POST_INSPECTION_X_NO_ACCESS ( $t$-statistic): 6.04

Model (2): Test for differences POST_INSPECTION_X_ACCESS \& POST_INSPECTION_X_NO_ACCESS ( $t$-statistic): 8.50

Table 4 presents the estimates of the regressions on absolute discretionary accruals $(|D A C C|)$ while considering whether PCAOB inspections are permitted in subsidiary countries. International subsidiaries are treated if the auditor of their foreign U.S.-listed GUO is initially PCAOB-inspected during our sample period. We retain observations of international subsidiaries for the control group if they are in the country-industry-year combinations of treated observations. We require control subsidiaries to have a foreign U.S.-listed GUO whose auditor is not initially PCAOB-inspected before or during our sample period. INSPECTION equals one for our 
treated sample of subsidiaries with an initial PCAOB inspection of their GUO auditor, and zero otherwise. POST_INSPECTION_X_ACCESS equals one for the first year following the final report year of the initial PCAOB inspection of a GUO's auditor if PCAOB inspections are permitted in the subsidiary country, and zero otherwise. POST_INSPECTION_X_NO_ACCESS equals one for the first year following the final report year of the initial PCAOB inspection of a GUO's auditor if PCAOB inspections are prohibited in the subsidiary country, and zero otherwise. SIZE denotes the natural logarithm of total assets. ROA measures the absolute value of return on assets, CFO the absolute value of cash flow from operations scaled by total assets, and TURNOVER_GROWTH the percentage change in turnover compared to the previous year. LOSS is an indicator variable that equals one for years following a loss year. $L E V E R A G E$ denotes the ratio of total debt scaled by total assets. SD_CFO and SD_TURNOVER denote the standard deviation of the cash flow from operations and turnover. We include year, subsidiary-industry (primary two-digit NACE Rev. 2 codes), subsidiary-country, and group fixed effects in all models. Standard errors are clustered at the subsidiary-country and subsidiary-industry level. All continuous variables are winsorized at the upper and lower $1 \%$ level of their distributions. $t$-statistics are presented in parentheses and calculated based on robust standard errors. * $* *$, and $* * *$ represent significance at the $10 \%, 5 \%$, and $1 \%$ level, respectively. 
Table 5

Robustness Tests

$\underline{\text { Panel A: GUO Earnings Management Incentives }}$

\begin{tabular}{|c|c|c|c|c|c|}
\hline & $\begin{array}{c}(1) \\
|D A C C|\end{array}$ & $\begin{array}{c}(2) \\
|D A C C|\end{array}$ & $\begin{array}{c}(3) \\
|D A C C|\end{array}$ & $\begin{array}{c}(4) \\
|D A C C|\end{array}$ & $\begin{array}{c}(5) \\
|D A C C|\end{array}$ \\
\hline INSPECTION & $\begin{array}{c}0.0702 * * \\
(2.161)\end{array}$ & $\begin{array}{c}0.0707 * * \\
(2.156)\end{array}$ & $\begin{array}{c}0.0698 * * \\
(2.145)\end{array}$ & $\begin{array}{c}0.0754 * * \\
(2.337)\end{array}$ & $\begin{array}{c}0.0748 * * \\
(2.308)\end{array}$ \\
\hline POST_INSPECTION & $\begin{array}{c}-0.0683 * * \\
(-2.077)\end{array}$ & $\begin{array}{l}-0.0695^{*} \\
(-2.035)\end{array}$ & $\begin{array}{c}-0.0683 * * \\
(-2.068)\end{array}$ & $\begin{array}{l}-0.0649 * \\
(-1.746)\end{array}$ & $\begin{array}{l}-0.0665^{*} \\
(-1.717)\end{array}$ \\
\hline SIZE & $\begin{array}{c}-0.00993 * * * \\
(-2.854)\end{array}$ & $\begin{array}{c}-0.00995 * * * \\
(-2.901)\end{array}$ & $\begin{array}{c}-0.00999 \\
(-1.682)\end{array}$ & $\begin{array}{c}-0.00995 * * * \\
(-3.259)\end{array}$ & $\begin{array}{c}-0.00998 * * \\
(-2.077)\end{array}$ \\
\hline$R O A$ & $\begin{array}{l}-0.0950 \\
(-1.383)\end{array}$ & $\begin{array}{l}-0.0948 \\
(-1.376)\end{array}$ & $\begin{array}{l}-0.0928 \\
(-1.317)\end{array}$ & $\begin{array}{l}-0.0939 \\
(-1.362)\end{array}$ & $\begin{array}{l}-0.0942 \\
(-1.327)\end{array}$ \\
\hline CFO & $\begin{array}{c}0.529 * * * \\
(16.02)\end{array}$ & $\begin{array}{c}0.529 * * * \\
(15.98)\end{array}$ & $\begin{array}{c}0.528 * * * \\
(15.46)\end{array}$ & $\begin{array}{c}0.528 * * * \\
(15.77)\end{array}$ & $\begin{array}{c}0.528 * * * \\
(15.10)\end{array}$ \\
\hline TURNOVER_GROWTH & $\begin{array}{c}0.104 * * * \\
(5.905)\end{array}$ & $\begin{array}{c}0.104 * * * \\
(5.980)\end{array}$ & $\begin{array}{c}0.103 * * * \\
(5.780)\end{array}$ & $\begin{array}{c}0.103 * * * \\
(5.354)\end{array}$ & $\begin{array}{c}0.103 * * * \\
(5.381)\end{array}$ \\
\hline LOSS & $\begin{array}{l}0.0251 \\
(1.287)\end{array}$ & $\begin{array}{l}0.0253 \\
(1.306)\end{array}$ & $\begin{array}{l}0.0250 \\
(1.227)\end{array}$ & $\begin{array}{l}0.0248 \\
(1.317)\end{array}$ & $\begin{array}{l}0.0251 \\
(1.274)\end{array}$ \\
\hline LEVERAGE & $\begin{array}{l}0.0199 \\
(0.710)\end{array}$ & $\begin{array}{l}0.0200 \\
(0.710)\end{array}$ & $\begin{array}{l}0.0201 \\
(0.728)\end{array}$ & $\begin{array}{l}0.0201 \\
(0.715)\end{array}$ & $\begin{array}{l}0.0196 \\
(0.707)\end{array}$ \\
\hline$S D \_C F O$ & $\begin{array}{c}0.159 * * * \\
(5.104)\end{array}$ & $\begin{array}{c}0.159 * * * \\
(5.089)\end{array}$ & $\begin{array}{c}0.159 * * * \\
(5.102)\end{array}$ & $\begin{array}{c}0.160 * * * \\
(4.720)\end{array}$ & $\begin{array}{c}0.160 * * * \\
(4.727)\end{array}$ \\
\hline SD_TURNOVER & $\begin{array}{c}0.0200 * \\
(1.782)\end{array}$ & $\begin{array}{c}0.0201 * \\
(1.765)\end{array}$ & $\begin{array}{c}0.0198^{*} \\
(1.835)\end{array}$ & $\begin{array}{l}0.0198 \\
(1.565)\end{array}$ & $\begin{array}{l}0.0197 \\
(1.474)\end{array}$ \\
\hline GUO_BIG4_AUDITOR & $\begin{array}{c}-0.538 * * \\
(-2.569)\end{array}$ & & & & $\begin{array}{l}-0.539 * * \\
(-2.702)\end{array}$ \\
\hline GUO_SMALL_GAIN & & $\begin{array}{l}-0.0136 \\
(-0.669)\end{array}$ & & & $\begin{array}{l}-0.0144 \\
(-0.690)\end{array}$ \\
\hline GUO_FIN_CONSTRAINTS & & & $\begin{array}{c}0.103 * * * \\
(2.811)\end{array}$ & & $\begin{array}{c}0.102 * * * \\
(3.036)\end{array}$ \\
\hline D_TAX & & & & $\begin{array}{c}-0.291 \\
(-0.979)\end{array}$ & $\begin{array}{c}-0.254 \\
(-0.847)\end{array}$ \\
\hline Observations & 3,559 & 3,559 & 3,559 & 3,559 & 3,559 \\
\hline R-squared & 0.413 & 0.413 & 0.413 & 0.413 & 0.414 \\
\hline Year FE & & & Yes & & \\
\hline Subsidiary-Industry FE & & & Yes & & \\
\hline Subsidiary-Country FE & & & Yes & & \\
\hline $\begin{array}{l}\text { Group FE } \\
\text { SE Clustering }\end{array}$ & & Subsidiary- & $\begin{array}{c}\text { Yes } \\
\text { Intry \& Su}\end{array}$ & diary-Industry & \\
\hline
\end{tabular}


Table 5 (continued)

$\underline{\text { Panel B: Exclusion of Observations from Countries with most Observations }}$

Sample without Subsidiaries from France

(1)

(2)

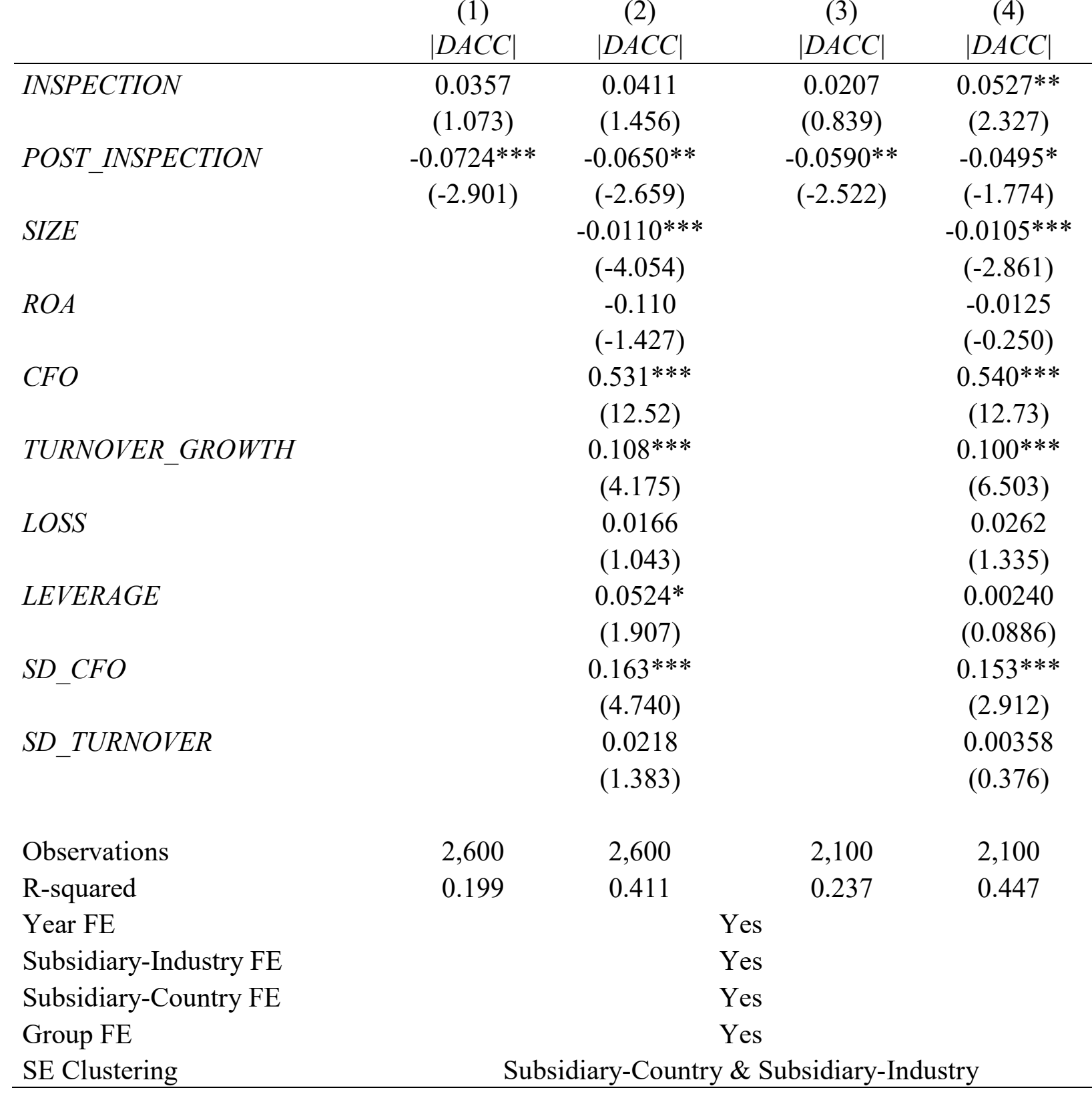


Table 5 (continued)

Panel C: Validation of Earnings Management Measure

\begin{tabular}{|c|c|c|}
\hline & $\begin{array}{c}(1) \\
|D A C C|\end{array}$ & $\begin{array}{c}(2) \\
|D A C C c|\end{array}$ \\
\hline INSPECTION & $\begin{array}{c}0.0697 * \\
(1.972)\end{array}$ & $\begin{array}{l}0.0197 \\
(1.465)\end{array}$ \\
\hline POST_INSPECTION & $\begin{array}{c}-0.0690^{*} \\
(-2.015)\end{array}$ & $\begin{array}{c}-0.0493 * * \\
(-3.045)\end{array}$ \\
\hline SIZE & $\begin{array}{c}-0.00983 * * \\
(-2.525)\end{array}$ & $\begin{array}{l}-0.00488 \\
(-1.509)\end{array}$ \\
\hline$R O A$ & $\begin{array}{l}-0.0943 \\
(-1.369)\end{array}$ & $\begin{array}{l}-0.0357 \\
(-0.612)\end{array}$ \\
\hline CFO & $\begin{array}{c}0.527 * * * \\
(14.41)\end{array}$ & $\begin{array}{c}0.485 * * * \\
(34.26)\end{array}$ \\
\hline TURNOVER_GROWTH & $\begin{array}{l}0.0924 * * * \\
(3.479)\end{array}$ & $\begin{array}{l}0.0959 * * * \\
(6.744)\end{array}$ \\
\hline LOSS & $\begin{array}{l}0.0285 \\
(1.566)\end{array}$ & $\begin{array}{l}0.0221 * \\
(1.895)\end{array}$ \\
\hline LEVERAGE & $\begin{array}{l}0.0218 \\
(0.666)\end{array}$ & $\begin{array}{l}0.0208 \\
(1.477)\end{array}$ \\
\hline$S D \_C F O$ & $\begin{array}{c}0.163 * * * \\
(3.827)\end{array}$ & $\begin{array}{c}0.157 * * * \\
(4.425)\end{array}$ \\
\hline SD_TURNOVER & $\begin{array}{l}0.0206 \\
(1.609)\end{array}$ & $\begin{array}{l}0.00843 \\
(1.123)\end{array}$ \\
\hline$R E V \_R E C_{-} T A$ & $\begin{array}{c}0.00888 \\
(0.795)\end{array}$ & \\
\hline$L \_R O A$ & $\begin{array}{l}0.0119 \\
(0.334)\end{array}$ & \\
\hline L_INFLATION & $\begin{array}{l}0.000279 \\
(0.0818)\end{array}$ & \\
\hline$L_{-} G D P \_G R O W T H$ & $\begin{array}{l}0.0710 \\
(0.179)\end{array}$ & \\
\hline Observations & 3,559 & 3,553 \\
\hline R-squared & 0.414 & 0.352 \\
\hline Year FE & \multicolumn{2}{|c|}{ Yes } \\
\hline Subsidiary-Industry FE & \multicolumn{2}{|c|}{ Yes } \\
\hline Subsidiary-Country FE & \multicolumn{2}{|c|}{ Yes } \\
\hline $\begin{array}{l}\text { Group FE } \\
\text { SE Clustering }\end{array}$ & \multicolumn{2}{|c|}{$\begin{array}{l}\text { Subsidiary-Country \& } \\
\text { Subsidiary-Industry }\end{array}$} \\
\hline
\end{tabular}

Table 5 presents robustness tests for our main result. International subsidiaries are treated if the auditor of their foreign U.S.-listed GUO is initially PCAOB-inspected during our sample period. We retain observations of 
international subsidiaries for the control group if they are in the country-industry-year combinations of treated observations. We require control subsidiaries to have a foreign U.S.-listed GUO whose auditor is not initially PCAOB-inspected before or during our sample period. INSPECTION equals one for our treated sample of subsidiaries with an initial PCAOB inspection of their GUO auditor, and zero otherwise. POST INSPECTION equals one for the first year following the final report year of the initial PCAOB inspection of a GUO's auditor, and zero otherwise. SIZE denotes the natural logarithm of total assets. $R O A$ measures the absolute value of return on assets, $C F O$ the absolute value of cash flow from operations scaled by total assets, and TURNOVER_GROWTH the percentage change in turnover compared to the previous year. LOSS is an indicator variable that equals one for years following a loss year. $L E V E R A G E$ denotes the ratio of total debt scaled by total assets. SD_CFO and $S D$ TURNOVER denote the standard deviation of the cash flow from operations and turnover. Table 5 Panel A presents the estimates of the regressions on absolute discretionary accruals $(|D A C C|)$ controlling for GUO earnings management incentives. GUO_BIG4_AUDITOR is an indicator variable set to one if the GUO is audited by KPMG, PwC, Ernst \& Young, or Deloitte. GUO_SMALL_GAIN is an indicator variable that equals one if the GUO reports a net profit in the consolidated financial statement that is less than $1 \%$ of total assets, and zero otherwise. GUO FIN CONSTRAINTS is an indicator variable set to one if the CFO of the GUO scaled by current assets at the end of the previous year is below -0.5 , and zero otherwise. D_TAX denotes the difference in corporate tax rates between the subsidiary country and the GUO country. Table 5 Panel B presents the estimates of the regressions on absolute discretionary accruals $(|D A C C|)$ with the exclusion of subsidiary-year observations from France in model (1) and (2) and with GUOs from Japan in model (3) and (4). Table 5 Panel C presents the estimates of the regression on absolute earnings management measures in two different research designs. In model (1), the dependent variable $|D A C C|$ denotes our basic measure of absolute discretionary accruals constructed by pooling regressions across years and subsidiary-industries (primary two-digit NACE Rev. 2 codes). REV_REC_TA denotes the difference in the change of revenue and receivables from $t-1$ to $t$ scaled by lagged total assets. $L \_R \overline{O A}$ measures the absolute value of return on assets in the previous year. L_INFLATION and $L_{-} G D P \_G R O \bar{W} T H$ denote the inflation and growth in GDP of the previous year. Model (2) applies $|D A C C c|$ as dependent variable, that is constructed by pooling regressions across years, subsidiary industries (primary NACE Rev. 2 sections), and subsidiary countries. For both fixed effects and standard errors we classify subsidiary industry by primary NACE Rev. 2 sections in model (2). If not specified differently, we include year, subsidiary-industry (primary two-digit NACE Rev. 2 codes), subsidiary-country, and group fixed effects in all panels of Table 5. Standard errors are clustered at the subsidiary-country and subsidiary-industry level. All continuous variables are winsorized at the upper and lower $1 \%$ level of their distributions. $t$-statistics are presented in parentheses and calculated based on robust standard errors. $*, * *$, and $* * *$ represent significance at the $10 \%, 5 \%$, and $1 \%$ level, respectively. 